\title{
PENGATURAN CSR MENUJU PEMBANGUNAN BERKELANJUTAN
}


Hak cipta pada penulis

Hak penerbitan pada penerbit

Tidak boleh diproduksi sebagian atau seluruhnya dalam bentuk apapun

Tanpa izin tertulis dari pengarang dan/atau penerbit

\section{Kutipan Pasal 72 :}

Sanksi pelanggaran Undang-undang Hak Cipta (UU No. 10 Tahun 2012)

1. Barang siapa dengan sengaja dan tanpa hak melakukan perbuatan sebagaimana dimaksud dalam Pasal 2 ayat (1) atau Pasal (49) ayat (1) dan ayat (2) dipidana dengan pidana penjara masing-masing paling singkat 1 (satu) bulan dan/ atau denda paling sedikit Rp. 1. 000.000,00 (satu juta rupiah), atau pidana penjara paling lama 7 (tujuh) tahun dan atau denda paling banyak Rp. 5 . 000.000.000,00 (lima miliar rupiah)

2. Barang siapa dengan sengaja menyiarkan, memamerkan, mengedarkan, atau menjual kepada umum suatu Ciptaan atau hasil barang hasil pelanggaran Hak Cipta atau Hak Terkait sebagaimana dimaksud ayat (1) dipidana dengan pidana penjara paling lama 5 (lima) tahun dan/atau denda paling banyak Rp. $500.000 .000,00$ (lima ratus juta rupiah) 


\section{PENGATURAN CSR MENUJU PEMBANGUNAN BERKELANJUTAN}

Lina Maulidiana 
Perpustakaan Nasional RI:

Katalog Dalam Terbitan (KDT)

\section{PENGATURAN CSR MENUJU PEMBANGUNAN BERKELANJUTAN}

Penulis:

Lina Maulidiana

\section{Editor:}

Oki Hajiansyah Wahab

Desain Cover \& Layout

Team Aura Creative

Penerbit

AURA

CV. Anugrah Utama Raharja

Anggota IKAPI

No.003/LPU/2013

$\mathrm{x}+73 \mathrm{hal}: 15 \times 23 \mathrm{~cm}$

Cetakan, Januari 2018

ISBN: 978-602-5636-2303

Alamat

Jl. Prof. Dr. Soemantri Brojonegoro, Komplek Unila Gedongmeneng Bandar Lampung

HP. 081281430268 E-mail: redaksiaura@gmail.com

Website : www.aura-publishing.com

Hak Cipta dilindungi Undang-undang 


\section{Dari Penulis}

Alhamdullilah, dengan izin Allah SWT penulisan buku sederhana berjudul ini berhasil diselesaikan ditengah kesibukan menjalankan aktifitas keseharian sebagai pengajar di Fakultas Hukum Universitas Saburai dan juga menyelesaikan studi di Program Doktor Ilmu Hukum Universitas Borobodur

Naskah buku ini sendiri dikembangkan dari hasil riset yang penulis lakukan yang selanjutnya dikembangkan menjadi buku teks untuk mendukung proses pembelajaran. Realitas saat ini yang tak bisa dipungkirti tentunya adalah masih banyak perusahaan terutama di daerah yang belum melaksanakan Corporate Social Responsibility (CSR) atau Tanggung Jawab Sosial Perusahaan (TSP). Hal ini menunjukkan bahwa masih banyak perusahaan yang tidak peduli pada masyarakat dan lingkungan di sekitarnya. Sebaliknya justru keberadaan perusahaan sering menimbulkan dampak negatif, baik di bidang sosial, ekonomi, dan lingkungan hidup.

Akibatnya di banyak tempat masih sering terjadi gesekan atau konflik antara masyarakat setempat dengan perusahaan. Sementara itu perusahaan yang telah melaksanakan TSP pada umumnya masih dalam bentuk charity yang bersifat spontan dan ad hoc atau sementara, dan belum sampai tingkat community development. TSP dalam bentuk charity tidak akan banyak membantu pemerintah daerah dalam menangani permasalahan sosial seperti tingginya kemiskinan, pengangguran, dan kerusakan lingkungan. 
Penulis mendedikasikan buku sederhana ini untuk suami tercinta Umar Usman dan anak-anak Raisya Augusta Putri (alm), Yolanda Septiani Thalita dan Jenika Tri Lestari. Juga kepada para kolega di Fakultas Hukum Universitas Saburai. Semoga kita semua tak pernah berhenti belajar.

Akhirnya penulis mengucapkan terima kasih kepada Aura Publishing yang telah berkenan menerbitkan buku ini.

vi

Bandar Lampung, Januari 2018

Penulis 


\section{Daftar Isi}

Dari Penulis ..........................................................................

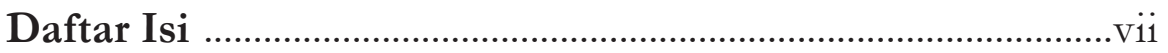

Daftar Tabel ........................................................................ viii

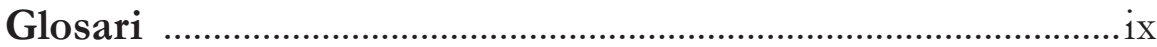

\section{Bagian I}

Dunia Industri, CSR dan Ekonomi Berkelanjutan ........................ 1

\section{Bagian II}

Tentang Corporate Social Responsibilty (CSR) ............................. 10

\section{Bagian III}

Landasan Filosofis, Yuridis dan Yuridis Pengaturan CSR ..........34

\section{Bagian IV}

Analisis Peraturan Perundang-Undangan Terkait CSR

Bagian V

Penutup 64

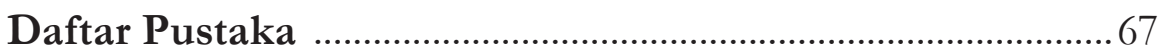

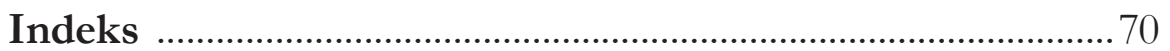

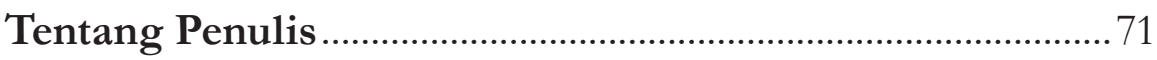




\section{Daftar Tabel}

Tabel 1

Pandangan Terkait CSR ………………………………………......... 14

viii Tabel 2

Model Kinerja Sosial Perusahaan ala Wartick dan Cochran ........ 16 


\section{Glosari}

CSR

Industri

Pembangunan : Proses pembangunan (lahan, kota, bisnis, masyarakat, Berkelanjutan

Pengusaha : Menurut Pasal 1 ayat (5) Undang-Undang Nomor 13 Tahun 2003 tentang Ketenagakerjaan, Pengusaha adalah:

a. Orang perseorangan, persekutuan, atau badan hukum yang menjalankan perusahaan milik sendiri;

b. Orang perseorangan, persekutuan, atau badan hukum yang secara berdiri sendiri menjalankan perusahaan bukan miliknya; 
Perusahaan : Menurut Pasal 1 ayat (6) Undang-Undang No.. 13 tahun 2003 tentang Perusahaan adalah:

a. Setiap bentuk usaha yang berbadan hukum atau tidak, milik orang perseorangan, milik persekutuan, atau milik badan hukum baik milik swasta maupun milik Negara yang memepekerjakan pekerja/buruh dengan membayar upah atau imbalan dalam bentuk lain.

b. Usaha-usaha social dan usaha-usaha lain yang mempunyai pengurus dan mempekerjakan orang lain dengan membayar upah atau imbalan dalam bentuk lain. 


\section{BAGIAN I \\ Dunia Industri, CSR dan Ekonomi Berkelanjutan}

$\mathrm{P}$

erkembangan dunia industri saat ini tidak hanya menggali be-

an (finansial) perusahaan, melainkan juga menyoroti relasi sosial antara perusahaan dengan masyarakat di sekitar perusahaan tersebut. Penyelenggaraan program tanggung jawab sosial perusahaan menjadi wadah bagi perusahaan menunjukkan eksistensinya bagi masyarakat dan kepeduliannya terhadap lingkungan sekitar yang menerima dampak dari pengelolaan sumber daya alam. Oleh karena itu, tanggung jawab sosial perusahaan menjadi kewajiban bagi perusahaan yang menjalankan kegiatan usahanya di bidang dan/ atau berkaitan dengan sumber daya alam.

Corporate Social Responsibility (CSR) adalah sebagai bentuk upaya kepedulian kalangan dunia usaha terhadap lingkungan di sekitarnya. Kegiatan CSR yang dilakukan berkenaan dengan berbagai bidang, mulai dari pendidikan, kesehatan, ekonomi, lingkungan bahkan sosial budaya. Konsep CSR sebagai bentuk tanggung jawab sosial perusahaan sudah mulai dikenal semenjak tahun 1970 an, namun mulai berkembang pesat di Indonesia sejak tahun 2000.

Di Indonesia kegiatan CSR ini dilaksanakan dalam berbagai pendekatan antara lain seperti pemberian amal perusahaan (corporate giving/charity), kedermawanan perusahaan (corporate philanthropy), relasi kemasyarakatan perusahaan (corporate community/pub- 
lic relation), dan pengembangan masyarakat (community development). Kegiatan community development atau dikenal juga dengan ComDev adalah bentuk pelaksanaan CSR yang paling sering dilakukan di Indonesia saat ini bahkan ComDev sudah diidentikkan dengan CSR. Sebenarnya CSR bukanlah semata-mata commununity development

Kegiatan community development (ComDev) ini dalam beberapa 2 aspek sebenarnya masih diwarnai oleh konsep filantropi yang lebih bersifat doing good to look good dan bersifat ad hoc. Seiring dengan perkembangan zaman, kegiatan CSR yang bersifat ad hoc sudah mulai ditinggalkan oleh sebagian besar perusahaan karena mereka mulai menyadari bahwa ujung tombak inovasi dan mendapatkan manfaat dari kegiatan CSR adalah dengan ikut menanggulangi permasalahan sosial dan lingkungan sebagai kegiatan CSR yang diintegrasikan sejak awal kedalam bisnis perusahaan ${ }^{2}$.

Kesadaran tentang pentingnya TSP ini menjadi trend global dengan mangkin banyaknya kepedulian mengutamakan pemangku kepentingan. TSP ini selain wujud penerapan prinsip good corporate governance juga merupakan upaya mendukung pencapaian tujuan Millennium Development Goals (MDG's), diantaranya adalah pengurangan angka kemiskinan setiap tahun. Dengan kata lain, meskipun sebagai entitas bisnis, perusahaan selain dituntut untuk mewujudkan kepentingan para shareholders tetapi juga sekaligus harus memperhatikan kepentingan para stakeholders.

Di era reformasi dan demokrasi sekarang ini, perusahaan-perusahaan tidak bisa lagi mengabaikan etika atau nilai-nilai mo-

\footnotetext{
1 J. Ambadar, dalam Petunjuk Pelaksanaan CSR Bidang Lingkungan, Kementerian Lingkungan Hidup. 2012.

2 Ibid.
} 
ral serta hak asasi manusia. Perusahaan dituntut untuk ikut serta memperhatikan nilai-nilai ketertiban, keadilan, dan kesejahteraan masyarakat serta menjaga kelangsungan lingkungan hidup dengan menghindari hal-hal dimungkinkanya menimbulkan kerusakan lingkungan hidup demi kesejahteraan bersama.

Tuntutan dan kondisi ideal yang diuraikan di atas pada kenyataannya masih harus lebih nyata yang diperjuangkan, mengingat masih banyaknya fakta yang menunjukkan pada hal-hal yang bukan semestinya, yaitu adanya ketidak harmonisan baik antara pihak perusahaan dengan masyarakat ataupun antara pihak perusahaan dengan lingkungannya. Yoserwan sebagaimana dikutip oleh Hasim Purba ${ }^{3}$ menyatakan bahwa fenomena yang dapat disaksikan adalah semakin seringnya terjadi pertentangan antara perusahaan disatu pihak dengan masyarakat di pihak lain. Perusahaan yang dimotivasi profit oriented acapkali mengabaikan prinsip CSR. Gejala seperti ini dapat disaksikan di berbagai wilayah di Indonesia, dari kota sampai ke desa-desa.

Banyak rentetan data kasus mengenai dampak negatif praktek bisnis yang berdampak pada tatanan sosial dan lingkungan di antaranya, kebocoran reaktor nuklir Chernobyl, Ukraina (1986); eksekusi mati Ken Saro-Wiwa (1995) diikuti gerakan separatis MOSOP (Movement for the Survival of the Ogoni People) sebagai representasi kekecewaan masyarakat sipil terhadap ketidak adilan pemerintah Nigeria dan Shell; blokade aktivis Greenpeace terhadap aksi penenggelaman bekas rig milik Shell di Laut Atlantik Utara dalam peristiwa Brent Spar (1995); sampai pada peristiwa dehumanisasi dan penghancuran lingkungan yang terjadi di Indonesia.

\footnotetext{
${ }^{3}$ HasimPurba, ImplementasiPrinsip CorporateSocialResponsibility (CSR) dalam Sistem Hukum Indonesia, http://repository.usu.ac.id/bitstream/123456789/18416/1/ equ-feb2008-13\%20 (1).pdf, Diakses tanggal 12 Nopember 2010.
} 
Penculikan dan eksekusi terhadap Marsinah (1994), konflik tidak berkesudahan antara masyarakat adat Papua dengan PT Freeport Indonesia dan Pemerintah serta peristiwa semburan lumpur panas dari ladang eksplorasi Lapindo Brantas di Sidoarjo lebih dari satu tahun belakangan ini adalah segejlintir contoh dampak negatif keberadaan industri di Indonesia.

Oleh karena itu, Pemerintah meminta komitmen swasta secara

4 khusus sebagai wujud pertanggungjawabab atas dampat negatif yang ditimbulkan. CSR merupakan suatu bentuk komitmen perusahaan untuk membangun kualitas kehidupan yang lebih baik bersama stakeholder terkait, terutama adalah masyarakat di sekeliling dimana perusahaan tersebut berada. Peran CSR semakin penting dalam mendorong semakin luasnya tanggung jawab sosial korporat bagi terciptanya keseimbangan pembangunan baik ekonomi, sosial maupun lingkungan.

Hal ini juga berangkat dari kenyataan bahwa selain sebagai institusi ekonomi, perusahaan juga control merupakan institusi sosial, dengan demikian diharapkan perusahaan dapat maju dan berkembang secara harmonis bersama masyarakat sekitar perusahaan. Komitmen tersebut tercermin dalam Keputusan Menteri Keuangan Republik Indonesia No. 316/KMK 016/1994 tentang Program Pembinaan Usaha Kecil dan Koperasi oleh Badan Usaha Milik Negara. Melalui kebijakan ini BUMN diwajibkan untuk turut serta dalam meningkatkan kesejahteraan masyarakat dan lingkungan sekitarnya melalui program PKBL(Program Kemitraan dan Bina Lingkungan) dengan cara menyisihkan sebagain laba dari perusahaan. ${ }^{4}$ Kebijakan tersebut kemudian diperbaharui dengan

\footnotetext{
${ }^{4}$ Laporan Program Kemitraan dan Bina Lingkungan Tahun 2007 PT. Bio farma (PERSERO).
} 
dikeluarkannya Keputusan Menteri Negara Badan Usaha Milik Negara no. Kep-236/MBU/2003 tentang Program Kemitraan Badan Usaha Milik Negara dengan Usaha Kecil dan Program Bina Lingkungan, yang sebelumnya dituangkan dalam Keputusan Menteri Keuangan Republik Indonesia No. 316/KMK 016/1994 juga tentang Program Pembinaan Usaha Kecil dan Koperasi oleh Badan Usaha Milik Negara. ${ }^{5}$

Faktanya, tidak semua perusahaan melaksanakan kewajiban CSR-nya. Perusahaan tersebut menganggap CSR sebagai sebuah pemborosan, karena anggaran perusahaan terserap untuk kegiatan yang tidak mendatangkan keuntungan. Jika dilaksanakan, praktek CSR yang terjadi sekarang ini berindikasi pada praktek public relation belaka sehingga terkesan imagesentris dan mendahulukan program-program yang bisa dilihat oleh publik (sebagai strategi komunikasi) dibandingkan melihat ke dalam perusahaan yang pada dasarnya memiliki posisi yang sama di dalam stakeholder CSR, yaitu buruh. Di satu sisi mengklaim telah meningkatkan standar sosial dan lingkungan pada proses operasi atau di perusahaan intinya, akan tetapi secara bersamaan menutup mata pada pelanggaran standar perburuhan atau lingkungan yang dilakukan subsidiary atau perusahaan-perusahaan dalam supply-chain mereka.

Implikasi negatif lain muncul manakala program CSR itu sendiri tidak termanfaatkan oleh masyarakat dengan baik. Bantuan finansial yang didapat oleh masyarakat, justru tidak dipergunakan untuk kepentingan modal usaha, melainkan untuk memenuhi dan membeli kebutuhan lain. Hal ini berujung pada tidak meningkatnya kualitas kehidupan masyarakat, indikasinya terlihat pada belum menurunnya angka kemiskinan. 
Hukum yang mengatur secara tegas masalah CSR telah ditetapkan di dalam Undang-Undang Nomor 25 Tahun 2007 tentang Penanaman Modal (UUPM $)^{6}$ dan Undang-Undang Nomor 40 Tahun 2007 tentang Perseroan Terbatas (UUPT). ${ }^{7}$ Ketika CSR dielaborasi oleh kedua undang-undang tersebut timbul beberapa kontroversi baik yang berkaitan dengan konsep CSR maupun yang berkaitan dengan tanggung jawab yang diderivasi dari etika bisnis menjadi sebuah norma hukum serta di dalam pelaksanaannya.

Undang-Undang Nomor 40 Tahun 2007 tentang Perseroan Terbatas mengatur mengenai Tanggung Jawab Sosial dan Lingkungan yang bertujuan untuk mewujudkan pembangunan ekonomi berkelanjutan guna meningkatkan kualitas kehidupan dan lingkungan yang bermanfaat bagi Perseroan itu sendiri, komunitas setempat, dan masyarakat pada umumnya. Ketentuan ini dimaksudkan untuk mendukung terjalinnya hubungan Perseroan yang serasi, seimbang, dan sesuai dengan lingkungan, nilai, norma, dan budaya masyarakat setempat, maka ditentukan bahwa Perseroan yang kegiatan usahanya di bidang dan/atau berkaitan dengan sumber daya alam wajib melaksanakan Tanggung Jawab Sosial dan Lingkungan.

6 Pasal 15 huruf b UUPM menyatakan bahwa setiap penanam modal berkewajiban melaksanakan tanggung jawab sosial perusahaan.

7 Pasal 74 UUPT menyatakan: (1) Perseroan yang menjalankan kegiatan usahanya di bidang dan/atau berkaitan dengan sumber daya alam wajib melaksanakan tanggung jawab sosial dan lingkungan; (2) Tanggung jawab sosial dan lingkungan sebagaimana dimaksud pada ayat (1) merupakan kewajiban perseroan yang dianggarkan dan diperhitungkan sebagai biaya perseroan yang pelaksanaannya dengan memperhatikan kepatutan dan kewajaran; (3) Perseroan yang tidak melaksanakan kewajiban sebagaimana dimaksud pada ayat (1) dikenakan sanksi sesuai dengan ketentuan peraturan perundang-undangan; (4) Ketentuan lebih lanjut mengenai tanggung jawab sosial dab lingkungan diatur dengan Peraturan pemerintah. 
Terkait dengan tujuan di atas, dalam kenyataannya saat ini masih banyak perusahaan di Indonesia yang mengartikan Corporate Social Responsibility (CSR) hanya sebagai kegiatan derma (charity) dan filantropis yang bersifat sesaat atau jangka pendek. Sesungguhnya Kegiatan CSR tak sekadar memberi sumbangan kepada masyarakat di sekitar perusahaan tapi juga melibatkan masyarakat dalam kegiatan bisnis di perusahaan.

Adanya CSR menjadikan paradigma dikotomi sektor publik dan sektor privat menjadi kabur. Manajemen problem dan kepentingan publik tidak lagi hanya menjadi kewajibannya administrasi negara, tapi dalam kasus tertentu juga melibatkan sektor non-government yakni sektor bisnis dan sektor ketiga (LSM dan organisasi non-profit). Oleh karena itu, agar perusahaan dapat menjalankan tanggung jawab sosialnya dengan baik, maka pemerintah atau organisasi publik harus dapat berfungsi menyediakan 'enabling environment" bagi CSR. World Bank mengklasifikasikan empat peran sektor publik dalam CSR: ${ }^{8}$ mandating, facilitating, partnering, endorsing.

Dalam menjalankan peran "mandating”, badan pemerintah merumuskan standar minimal kinerja bisnis yang tertuang dalam kerangka hukum. Misal menetapkan aturan nilai batas emisi untuk instalasi industri tertentu, atau menetapkan persyaratan agar faktor-faktor tertentu menjadi pertimbangan dalam pengambilan keputusan yang diambil oleh direktur perusahaan. Dalam menjalankan peran "facilitating", badan pemerintah menumbuhkan kondisi, memfasilitasi, atau memberi insentif agar perusahaan mau melaksanakan agenda CSR atau ikut terlibat dalam program perbaikan sosial dan lingkungan.

${ }^{8}$ Sri Yuliani. "Corporate Social Responsibility (CSR) : Pertanggungjawaban Publik Sektor Bisnis dan Implikasinya Bagi Studi Administrasi Publik". http://sriyuliani. staff.fisip.uns.ac.id. Dikases tanggal 1 Nopember 2011. 
Peran pemerintah di sini adalah sebagai catalytic atau pemberi dukungan (supporting role), misalnya dengan menyediakan dana bagi riset, penyebaran informasi, pelatihan ataupun kampanye penyadaran. Peran sebagai ,partnership“ merupakan peran penting dalam agenda CSR. Kemitraan strategis menjadi sarana berbagi skills dan input dari sektor publik, privat dan masyarakat sipil dalam mengatasi problem sosial dan lingkungan yang kompleks.

8 Dalam hal ini, pemerintah dapat menjalankan peran sebagai partisipan, penyelenggara konperensi (convenor), atau fasilitator. Peran keempat adalah peran memberi dukungan politik dan pengesahan (endorsement) atau legitimasi terhadap CSR. Peran pengesahan dapat mengambil berbagai bentuk, dapat melalui dokumen kebijakan, praktek manajemen sektor publik, penghargaan terhadap perusahaan yang menjalankan CSR, misalnya menyelenggarakan acara CSR Award.

Deskripsi peran pemerintah dalam CSR sebagaimana dilansir oleh World Bank menggambarkan bahwa pada tataran praktek tidak bisa dipisahkan secara tegas antara peran sektor bisnis di aktivitas ekonomi yang berorientasi profit dan sektor publik di aktivitas sosial politik yang berorientasi pada kepentingan publik. Pemerintah berperan penting dalam menciptakan kondisi yang kondusif bagi kegiatan bisnis yang sehat maupun dalam menfasilitasi Tanggung Jawab Sosial Perusahaan (CSR).

Uraian di atas menunjukkan bahwa di dalam membahas CSR banyak aspek yang mesti diperhatikan. Dilihat di dalam penerapannya, CSR di Indonesia masih banyak ditemukan tantangan mengingat belum adanya standarisasi CSR, kesatuan istilah, konsep, bentuk, maupun Peraturan Pemerintah tentang CSR. Di samping itu, pengaturan CSR ke dalam produk hukum itu sendi- 
ri pun menimbulkan pendapat yang berbeda antara yang pro dan yang kontra.

Berbagai argumentasi yang menolak CSR sebagai suatu kewajiban, melihat CSR pada tataran kewajiban saja. Para pelaku usaha tidak mengindahkan dasar filosofinya dan dampak yang berlangsung selama ini. Para pelaku usaha seringkali tidak melihat dari segi tanggung jawab kepada generasi berikutnya, terhadap apa yang telah mereka lakukan dan apa yang akan mereka wariskan kepada generasi akan datang.

9 Isa Wahyudi dan Busyra Azheri. Corporate Social Responsibility: Prinsip, Pengaturan dan Implementasi. Malang: Setara Press, 2011, hlm. 186. 


\section{BAGIAN II \\ Tentang Corporate Social Responsibilty (CSR)}

orporate Social Responsibility (CSR) atau Tanggung Jawab Sosial Perusahaan (TSP) merupakan salah satu isu yang mengglobal di samping isu demokrasi dan hak asasi manusia. Menurut Edi Suharto, ${ }^{10}$ CSR merupakan sebuah tuntutan global dimana keberhasilan perusahaan (korporasi) tidak hanya dinilai dari kinerja keuangan dan pemasaran produknya saja tetapi juga terhadap kinerja sosial dan lingkungannya. Secara konseptual, CSR juga bersinggungan dan bahkan sering dipertukarkan dengan frasa lain, seperti corporate responsibility, corporate sustainability, corporate accountability, corporate citizenship, dan corporate stewardship.

Pengertian tanggung jawab sosial perusahaan dibagi dalam 2 (dua) pengertian, yaitu dalam pengertian luas dan dalam pengertian sempit. Tanggung jawab sosial perusahaan dalam pengertian luas berkaitan erat dengan tujuan mencapai kegiatan ekonomi berkelanjutan (sustainable economic activity). Keberlanjutan kegiatan ekonomi bukan hanya terkait soal tanggung jawab sosial tetapi juga menyangkut akuntabilitas (accountibility) perusahaan terhadap masyarakat dan bangsa serta dunia internasional. Tanggung jawab sosial perusahaan dapat diuraikan sebagai bentuk kerjasama antara

${ }^{10}$ Edi Suharto, Corporate Social Responsibility : Konsep dan Perkembangan Pemikiran,. Makalah disampaikan pada Workshop Tanggungjawab Sosial Perusahaan, Universitas Islam Indonesia (UII), Yoyakarta, Tanggal 6-8 Mei 2008. 
perusahaan (tidak hanya perseroan terbatas) dengan segala hal (stakeholder) yang secara langsung maupun tidak langsung berinteraksi dengan perusahaan untuk tetap menjamin keberadaan dan kelangsungan hidup usaha (sustainability) perusahaan tersebut.

Secara normatif, defenisi perseroan sebagaimana disebutkan dalam Undang-Undang Nomor 40 Tahun 2007 tentang Perseroan Terbatas adalah badan hukum yang merupakan persekutuan modal, didirikan berdasarkan perjanjian, melakukan kegiatan usaha dengan modal dasar yang seluruhnya terbagi dalam saham dan memenuhi persyaratan yang ditetapkan dengan undang-undang ini serta peraturan pelaksanaannya. Ada pun tangung jawab sosial dan lingkungan dalam Undang-Undang ini diartikan sebagai komitmen perseroan untuk berperan serta dalam pembangunan ekonomi berkelanjutan guna meningkatkan kualitas kehidupan dan lingkungan yang bermanfaat bagi perseroan itu sendiri, komunitas setempat maupun masyarakat pada umumnya.

Ketentuan terkait tanggung jawab sosial perusahaan disebutkan secara gamblang dalam Pasal 74 Undang-Undang Nomor 40 Tahun 2007 tentang Perseroan Terbatas bahwa "Perseroan yang menjalankan kegiatan usahanya di bidang dan/atau berkaitan dengan sumber daya alam wajib melaksanakan tanggung jawab sosial dan lingkungan. Tanggung jawab sosial dan lingkungan merupakan kewajiban perseroan yang dianggarkan dan diperhitungkan sebagai biaya perseroan yang pelaksanaannya dilakukan dengan memperhatikan kepatutan dan kewajaran". Perseroan yang tidak melaksanakan kewajiban dikenai sanksi sesuai dengan ketentuan peraturan perundang-undangan.

Hal yang sama juga diatur Peraturan Pemerintah Nomor 47 Tahun 2012 tentang Tanggung Jawab Sosial dan Lingkungan 
Perseroan Terbatas. Tanggung jawab sosial perusahaan dilaksanakan oleh Direksi berdasarkan rencana kerja tahunan perusahaan setelah mendapat persetujuan Dewan Komisaris aau RUPS sesuai dengan anggaran dasar perusahaan, kecuali ditentukan lain dalam peraturan perundang-undangan seperti halnya persetujuan atas rencana kerja diberikan oleh RUPS, maka anggaran dasar tidak dapat menentukan rencana kerja disetujui oleh Dewan Komisaris 12 atau sebaliknya.

Rencana kerja tahunan perusahaan memuat rencana kegiatan dan anggaran yang dibutuhkan untuk pelaksanaan tanggung jawab sosial perusahaan. Perusahaan dalam menjalankan kegiatan usahanya di bidang dan/atau berkaitan dengan sumber daya alam, dalam menyusun dan menetapkan rencana kegiatan dan anggaran harus memperhatikan kepatutan dan kewajaran, yaitu kebijakan perusahaan yang disesuaikan dengan kemampuan keuangan perusahaan dan potensi risiko yang mengakibatkan tanggung jawab sosial perusahaan yang harus ditanggung oleh perusahaan sesuai dengan kegitan usahanya yang tidak mengurangi kewajiban sebagaimana yang ditetapkan dalam ketentuan peraturan perundangundangan yang terkait dengan kegiatan perusahaan. Realisasi anggaran untuk pelaksanaan tanggung jawab sosial perusahaan dilaksanakan oleh perusahaan diperhitungkan sebagai biaya perusahaan. Pelaksanaan tanggung jawab sosial perusahaan dimuat dalam laporan tahunan perusahaan dan dipertanggungjawabkan kepada RUPS.

Bagi perusahaan yang tidak melaksanakan tanggung jawab sosial perusahaan dikenai segala bentuk sanksi sesuai dengan ketentuan peraturan perundang-undangan terkait. Tanggung jawab sosial perusahaan tidak menghalangi perusahaan berperan serta 
melaksanakan tanggung jawab sosial perusahaannya, artinya perusahaan tetap dapat melakukan tanggung jawab sosial perusahaanya selain yang telah menjadi kewajibannya. Perusahaan yang telah berperan serta melaksanakan tanggung jawab sosial perusahaan dapat diberikan penghargaan oleh instansi yang berwenang, misalnya fasilitas atau bentuk penghargaan lainnya.

Terdapat 2 (dua) perspektif tentang tanggung jawab sosial perusahaan. Kedua perspektif ini tidak muncul begitu saja, melainkan muncul dari 2 (dua) cara pandang yaitu bagaimana peran bisnis dalam masyarakat. ${ }^{11}$ Cara pandang pertama, pandangan klasik (classical view), yang didasarkan pada teori ekonomi neo-klasik, melihat peran bisnis dalam masyarakat murni sebagai pencarian keuntungan, yaitu keuntungan bagi para pemegang saham (shareholder). Cara pandang ini disebut juga sebagai perspektif pemegang saham (shareholder perspective).

Sebaliknya, pandangan pemangku kepentingan (stakeholderview), yang didasarkan pada teori pemangku kepentingan berkeyakinan bahwa perusahaan memiliki tanggung jawab sosial. Tanggung jawab sosial itu menuntut perusahaan memiliki tanggung jawab sosial dan menuntut perusahaan untuk mempertimbangkan kepentingan semua pihak yang terkena pengaruh dari tindakannya. Gambaran singkatnya dapat dilihat pada tabel berikut:

${ }^{11}$ Manuel Castelo Branco dan Lúcia Lima Rodriguez, "Positioning Stakeholder Theory within the Debate on Corporate Social Responsibility", Elecrtonic Jpurnal of Business Ethics and Organizaion (EJBO), Vol. 12, No. 1 (2007), hal. 6, kolom 1, paragraf 1. 


\section{Tabel 1 Pandangan Terkait CSR}

\begin{tabular}{|c|c|}
\hline Pandangan & $\begin{array}{c}\text { Posisinya terhadap Peran Bisnis dalam } \\
\text { Masyarakat }\end{array}$ \\
\hline Klasik & a. $\begin{array}{l}\text { Pandangan pencarian keuntungan murni: } \\
\text { bisnis memiliki standar etis yang lebih } \\
\text { rendah dari pada masyarakat, bisnis } \\
\text { tidak memiliki tanggung jawab sosial } \\
\text { kecuali kepatuhan pada hukum. }\end{array}$ \\
b. $\begin{array}{l}\text { Pandangan pencarian keuntungan yang } \\
\text { terbatas: bisnis harus memaksimalkan } \\
\text { kekayaan para pemegang sahamnya, } \\
\text { mematuhi hukum dan bisnis itu memiliki } \\
\text { aspek etis. }\end{array}$ \\
\hline pemangku & a. $\begin{array}{l}\text { Pandangan berkesadaran sosial: bisnis } \\
\text { harus sensitif pada kerusakan potensial } \\
\text { dari tindakannya terhadap pelbagai kel- } \\
\text { ompok pemangku kepentingan. } \\
\text { Aktivisme sosial: bisnis harus meng- } \\
\text { gunakan segala sumber dayanya untuk } \\
\text { kepentingan publik. }\end{array}$ \\
\hline
\end{tabular}

Selain kedua hal tersebut di atas, masih ada sebuah konsep lain berkaitan dengan tanggung jawab sosial perusahaan, yaitu kinerja sosial perusahaan (corporate sosial performance). ${ }^{12}$ Kinerja sosial perusahaan memiliki 3 (tiga) aspek: pertama, defenisi tentang tanggung jawab sosial; kedua, identifikasi tentang isu-isu sosial yang terhadapnya tanggung jawab itu diarahkan, seperti konsumerisme, lingkungan, keamanan produk, diskriminasi buruh dan sebagainya; ketiga filosofi kepedulian yaitu filosofi, cara atau strategi di balik respons perusahaan terhadap tanggung jawab sosial dan isu-isu sosial (reaksi, pembelaan, akomodasi, proaksi dan sebagainya). ${ }^{13}$

\footnotetext{
12 Ibid.

13 Ibid.
} 
Pendapat lain ${ }^{14}$ mengajukan bahwa tanggung jawab sosial perusahaan melibatkan 4 (empat) kategori tanggung jawab sosial, yaitu:

1. Tanggung jawab ekonomis, mencerminkan keyakinan bahwa perusahaan memiliki kewajiban untuk menghasilkan barang dan jasa yang dibutuhkan konsumen dan dalam prosesnya akan mendatangkan keuntungan.

2. Tanggung jawab legal, menunjukkan bahwa perusahaan diharapkan memenuhi tanggung jawab ekonominya dalam tuntutan hukum tertulis.

3. Tanggung jawab etis, menunjukkan sebuah perhatian bahwa perusahaan memenuhi harapan masyarakat tentang tindakan bisnis yang tidak dikodifikasikan ke dalam hukum, tetapi lebih sebagai yang dicerminkan dalam standar, norma, nilai-nilai yang tidak tertulis yang secara implisit diturunkan dari masyarakat.

4. Tanggung jawab diskresionaris, perusahaan bersifat filantropik atau suka rela, dalam arti bahwa tanggung jawab ini merepresentasikan peran suka rela dari perusahaan terhadap harapan masyarakat yang tidak sejelas dalam tanggung jawab etis. Tanggung jawab etis dan diskresionaris melibatkan tanggung jawab yang lebih untuk melakukan apa yang baik dan menghindari cidera atau kerusakan.

Hubungan antara keempat tanggung jawab ini tampak sebagai piramida dimana bagian ekonomis menjadi dasar bagi 3 (tiga)

${ }^{14}$ A. B. Carroll, "A Three-Dimensional Conceptual Model of Corporate Social Performance", Academy of Management Review, Vol. 4. No. 4, 1979, hal. 497505. Lihat juga The Pyramid of Corporate Social Responsibiliy: Toward the Moral Management of Organizational Stakeholders, Business Horizons, Vol. 34, No. 4, 1991, hal. 39-48. 
tanggung jawab lainnya, tanggung jawab legal menjadi dasar bagi 2 (dua) tanggung jawab lainnya, dan seterusnya. Menurut Carroll, ${ }^{15}$ perusahaan harus mengisi keempat tanggung jawab tersebut secara simultan. Asumsi utama di balik perspektif ini yaitu persoalan ekonomi menjadi tanggung jawab masyarakat pebisnis, jadi bukan hanya urusan untuk perusahaan atau bisnis yang bersangkutan. Model Carrol diperluas dan dimodifikasi lebih lanjut oleh Wartick 16 dan Cochran ${ }^{16}$ dan Wood ${ }^{17}$ sebagaimana digambarkan dalam tabel berikut:

\section{Tabel 2 Model Kinerja Sosial Perusahaan ala Wartick dan Cochran}

\begin{tabular}{|c|c|c|}
\hline Prinsip & Proses & Kebijakan \\
\hline $\begin{array}{l}\text { Tanggung jawab so- } \\
\text { sial perusahaan: } \\
\text { (1) ekonomis } \\
\text { (2) legal } \\
\text { (3) etis } \\
\text { (4) diskresionari } \\
\quad \text { (filantropik) }\end{array}$ & $\begin{array}{l}\text { Kepedulian sosial } \\
\text { perusahaan: } \\
\text { (1) reaktif } \\
\text { (2) defensif } \\
\text { (3) akomodatif } \\
\text { (4) proaktif }\end{array}$ & $\begin{array}{l}\text { Manajemen isu sosial: } \\
\text { (1) identifikasi isu } \\
\text { (2) analisis isu } \\
\text { (3) pembangunan } \\
\quad \text { tanggapan }\end{array}$ \\
\hline $\begin{array}{l}\text { Diarahkan pada: } \\
\text { (1) kontrak sosial } \\
\text { bisnis } \\
\text { (2) bisnis sebagai } \\
\text { agen moral }\end{array}$ & 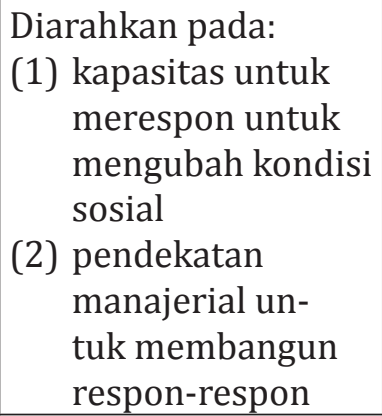 & $\begin{array}{l}\text { Diarahkan pada: } \\
\text { (1) meminimalisir } \\
\text { kejutan-kejutan } \\
\text { (2) menentukan } \\
\text { kebijakan sosial } \\
\text { perusahaan yang } \\
\text { efektif }\end{array}$ \\
\hline Orientasi filosofis & Orientasi institusional & $\begin{array}{c}\text { Orientasi } \\
\text { organisasional }\end{array}$ \\
\hline
\end{tabular}

15 Ibid.

${ }^{16}$ Manuel Castelo Branco dan Lúcia Lima Rodriguez, "Positioning.... Op. Cit., hal. 507.

17 Ibid. 
CSR merupakan konsep yang terus berkembang. Ia belum memiliki sebuah definisi standard ${ }^{18}$ maupun seperangkat kriteria spesifik yang diakui secara penuh oleh pihak-pihak yang terlibat di dalamnya. Menurut Soeharto Prawirokusumo, ${ }^{19}$ tanggung jawab sosial adalah sebuah konsep yang luas yang berhubungan dengan kewajiban perusahaan atau organisasi dalam memaksimumkan impact positif terhadap masyarakatnya. Tanggung jawab sosial para pelaku usaha dalam suatu perusahaan tersebut terdiri atas empat dimensi tanggung jawab yaitu; ekonomi, hukum, etika dan philanthropies.

Kesadaran tentang pentingnya TSP ini menjadi trend global seiring dengan semakin maraknya kepedulian mengutamakan pemangku kepentingan. TSP ini selain wujud penerapan prinsip good corporate governance juga terkait untuk mendukung pencapaian tujuan Millennium Development Goals (MDG's), salah satu diantaranya adalah pengurangan angka kemiskinan setiap tahun. Dengan kata lain, meskipun sebagai entitas bisnis, perusahaan tidak hanya dituntut untuk mewujudkan kepentingan para shareholders tetapi juga sekaligus harus memperhatikan kepentingan para stakeholders.

${ }^{18}$ Menurut Penjelasan Pasal 15 huruf b Undang-Undang No.25 Tahun 2007 tentang Penanaman Modal (UUPM) menyatakan bahwa yang dimaksud dengan "tanggung jawab sosial perusahaan" adalah tanggung jawab yang melekat pada setiap perusahaan penanaman modal untuk tetap menciptakan hubungan yang serasi, seimbang, dan sesuai dengan lingkungan, nilai, norma, dan budaya masyarakat setempat ". Sedangkan menurut Pasal 1 angka 3 Undang-Undang No. 40 Tahun 2007 tentang Perseroan Terbatas (UUPT) menggunakan terminologi tangung jawab sosial dan lingkungan yaitu komitmen perseroan untuk berperan serta dalam pembangunan ekonomi berkelanjutan guna meningkatkan kualitas kehidupan dan lingkungan yang bermanfaat, baik bagi perseroan sendiri, komunitas setempat maupun masyarakat pada umumnya.

19 Soeharto Prawirokusumo, Perilaku Bisnis Modern - Tinjauan pada Etika Bisnis dan Tanggung Jawab Sosial, Jurnal Hukum Bisnis, Vol 22, No 4, 2003, hlm. 83. 
Di era reformasi dan demokrasi sekarang ini, perusahaan perusahaan tidak bisa lagi mengabaikan etika atau nilai-nilai moral serta hak asasi manusia. Perusahaan dituntut untuk ikut serta memperhatikan nilai-nilai ketertiban, keadilan, dan kesejahteraan masyarakat serta menjaga kelangsungan lingkungan hidup dengan menghindari hal-hal yang bisa menimbulkan kerusakan lingkungan hidup demi kesejahteraan bersama.

Sayangnya, tuntutan dan kondisi ideal seperti diuraikan di atas dalam kenyataannya masih harus serius diperjuangkan, mengingat masih banyaknya fakta yang menunjukkan sebaliknya, yaitu adanya ketidakharonisan baik antara perusahaan dengan masyarakat ataupun antara perusahaan dengan lingkungannya. Yoserwan sebagaimana dikutip oleh Hasim Purba ${ }^{20}$ menyatakan bahwa fenomena yang dapat disaksikan adalah semakin seringnya terjadi pertentangan antara perusahaan disatu pihak dengan masyarakat di pihak lain. Perusahaan yang dimotivasi profit oriented acapkali mengabaikan prinsip CSR. Gejala seperti ini dapat disaksikan di berbagai wilayah di Indonesia, dari kota sampai ke desa-desa.

Semakin menguatnya tuntutan perusahaan melaksanakan CSR sebenarnya juga tidak terlepas dari kenyataan dimana keberadaan suatu perusahaan bisa berdampak negatif bagi sosial dan lingkungan disekitarnya. Poerwanto menyatakan ${ }^{21}$, CSR di dunia dan Indonesia kini telah menjadi isu penting berkaitan dengan masalah dampak lingkungan dalam pembangunan berkelanjutan. Hal tersebut muncul sebagai reaksi dari banyak pihak terhadap

\footnotetext{
20 Hasim Purba, Implementasi Prinsip Corporate Social Responsibility (CSR) dalam Sistem Hukum Indonesia, http://repository.usu.ac.id/ bitstream/123456789/18416/1/equ-feb2008-13\%20 (1).pdf, Diakses tanggal 12 Nopember 2010.
}

${ }^{21}$ Poerwanto. Corporate Social Responsibility : Menjinakkan Gejolak Sosial di Era Pornografi. Yogyakarta: Pustaka Pelajar, 2010, hlm.16. 
kerusakan lingkungan baik fisik, psikis maupun sosial, sebagai akibat dari pengelolaan sumber-sumber produksi secara tidak benar. FX. Adji Samekto ${ }^{22}$ menyatakan berbagai kerusakan lingkungan bersifat lintas batas negara kemudian muncul di dunia seperti perusakan lapisan ozon, terjadinya pemanasan global, berkurangnya keragaman hayati, terjadinya hujan asam, dan kerusakan-kerusakan lingkungan yang bersifat lokal.

Di sektor kehutanan ${ }^{23}$ kerusakan di Indonesia juga sangat memprihatinkan, di mana kerusakan hutan mencapai $55 \%$ atau hampir 23 juta hektar. Laju kerusakan hutan makin meningkat selama otonomi daerah, yaitu 2,5 juta/ha/tahun dengan tingkat kerusakan di urutan kedua setelah Brasil. Menurut Sukanda Husin ${ }^{24}$ sumber daya hutan dan lahan Indonesia telah berada pada titik ecological imbalances. Pada umumnya, hal ini disebabkan oleh eksploitasi besar-besaran serta tidak berkelanjutan dan tidak berwawasan ekologi sumber daya hutan, baik pengambilan hasil hutan, pembukaan lahan perkebunan, maupun untuk keperluan lain seperti pertambangan.

Suporahardjo menyatakan bahwa ${ }^{25}$ selama sepuluh tahun terakhir ini, kekerasan atau konflik sosial atas pengelolaan sumber

${ }^{22}$ FX. Adji Samekto. Kapitalisme, Modernisasi, dan Kerusakan Lingkungan. Yogyakarta: Genta Press, 2008, hlm. 97. Menurut Nor Hadi. Corporate Social Responsibility. Yogyakarta: Graha IImu, 2011, hlm. 39, terdapat tiga kategori dampak negatif perusahaan (industri) terhadap lingkungan, yaitu dampak karena input proses, dampak karena proses produksi, dan dampak karena output proses produksi.

${ }^{23}$ Sudharto P. Hadi dan FX. Adji Samekto. Dimensi Lingkungan dalam Bisnis Kajian Tanggung Jawab Sosial Perusahaan pada Lingkungan. Semarang: Badan Penerbit Universitas Diponegoro, 2007 hlm 3

${ }^{24}$ Sukanda Husin. Penegakkan Hukum Lingkungan Indonesia. Jakarta: Sinar Grafika, 2009, hlm. 82.

${ }^{25}$ Suporahardjo (Ed). Kekerasan dalam Kebijakan Pengelolaan Sumber Daya Hutan: Dalam Perspektif Hukum. Bogor: Pustaka Latin, 2006, hlm.4-5 
daya alam di wilayah Indonesia telah muncul kepermukaan dengan eskalasi yang sangat tinggi. Konflik ini antara lain termanifestasikan dalam bentuk sengketa tanah/sumber daya alam antara masyarakat lokal dengan aparatur pemerintah atau dengan perusahaan.

Pelaksanaan CSR di Indonesia masih menyisakan banyak masalah baik dari segi peraturan maupun dalam penegakan hu20 kumnya. Dalam dunia bisnis, hukum merupakan salah satu faktor pendukung untuk terciptanya kegiatan bisnis yang sehat. Terkait dengan hal itu, Bismar Nasution menyatakan supaya pembangunan ekonomi dilakukan berlandasan hukum dan pendidikan hukum dirancang sesuai dengan kebutuhan masyarakat. ${ }^{26}$ Sekarang ini, hukum yang mengatur secara tegas masalah CSR telah ditetapkan di dalam Undang-Undang Nomor 25 Tahun 2007 tentang Penanaman Modal (UUPM) ${ }^{27}$ dan Undang-Undang Nomor 40 Tahun 2007 tentang Perseroan Terbatas (UUPT). ${ }^{28}$ Ketika CSR dielaborasi oleh kedua undang-undang tersebut timbul beberapa kontroversi baik yang berkaitan dengan konsep CSR maupun yang berkaitan dengan tanggung jawab yang diderivasi dari etika bisnis menjadi sebuah norma hukum serta di dalam pelaksanaannya.

${ }^{26}$ Hasim Purba, Loc. Cit.

27 Pasal 15 huruf b UUPM menyatakan bahwa setiap penanam modal berkewajiban melaksanakan tanggung jawab sosial perusahaan.

${ }^{28}$ Pasal 74 UUPT menyatakan: (1) Perseroan yang menjalankan kegiatan usahanya di bidang dan/atau berkaitan dengan sumber daya alam wajib melaksanakan tanggung jawab sosial dan lingkungan; (2) Tanggung jawab sosial dan lingkungan sebagaimana dimaksud pada ayat (1) merupakan kewajiban perseroan yang dianggarkan dan diperhitungkan sebagai biaya perseroan yang pelaksanaannya dengan memperhatikan kepatutan dan kewajaran; (3) Perseroan yang tidak melaksanakan kewajiban sebagaimana dimaksud pada ayat (1) dikenakan sanksi sesuai dengan ketentuan peraturan perundang-undangan; (4) Ketentuan lebih lanjut mengenai tanggung jawab sosial dab lingkungan diatur dengan Peraturan pemerintah. 
Di Provinsi Lampung wacana tentang pentingnya perusahaan melaksanakan CSR semakin mengemuka mengingat masih banyak perusahaan yang belum melaksanakan program CSR. Diberitakan bahwa $^{29}$ sebanyak $75 \%$ perusahaan-perusahaan yang ada di Lampung belum melaksanakan CSR.

Fakta-fakta di atas menunjukkan bahwa keberadaan suatu perusahaan tidak bisa hanya berorientasi pada maksimalisasi keuntungan semata. Merrick Dodd sebagaimana dikutip Mukti Fajar ${ }^{30}$ mengajukan konsep bahwa korporasi bekerja tidak hanya untuk kepentingan pemegang saham, tetapi juga untuk kepentingan masyarakat umum dan kesejahteraan bangsa, yang selanjutnya lebih dikenal dengan istilah stakeholders.

Menurut R. Edward Freeman yang dimaksud stakeholders adalah pihak-pihak yang dipengaruhi sekaligus mempengaruhi tujuan pencapaian keuntungan perusahaan. Ajaran Dodd tersebut telah melahirkan stakeholders theory. Teori ini dibangun berdasarkan pandangan, apabila direksi korporasi hanya mencari keuntungan sebanyak-banyaknya demi kepentingan pemegang saham, maka kemungkinan besar bisnis akan cenderung menyimpang. Perusahaan akan melakukan eksploitasi terhadap buruh dan menekan konsumen serta rekanan bisnis. Untuk itu tujuan mencari keuntungan dari korporasi harus diperluas juga kepada pemenuhan kepentingan stakeholders.

Lebih lanjut Lukviarman sebagaimana dikutip G. Suprayitno $\mathrm{dkk},{ }^{31}$ menyatakan bahwa dalam perspektif stakeholders keberadaan

29 Harian Pagi Tribun Lampung, tanggal 19 Pebruari 2011.

${ }^{30}$ Mukti Fajar. Tanggung Jawab Sosial Perusahaan di Indonesia: Studi Tentang Penerapan Ketentuan Corporate Sosial Responbility pada Perusahaan Multi Nasional, Swasta Nasional dan Badan Usaha Milik Negara. Yogyakarta: Pustaka Pelajar, 2010, hlm. 98-99.

${ }^{31}$ G. Suprayitno., et al. Internalisasi Good Corporate Governance dalam Proses 
perusahaan selayaknya mengacu kepada peningkatan kemakmuran berbagi pihak petaruh secara lebih luas. Perspektif ini memberikan penekanan kepada perlunya: (a) partisipasi stakeholders di dalam pengambilan keputusan perusahaan, (b) hubungan kontraktual jangka panjang antara perusahaan dengan stakeholders, (c) hubungan berbasis kepercayaan (trust relationships), dan (d) berjalannya etika bisnis menyangkut hubungan perusahaan dengan pihak 22 lainnya.

Secara tegas Lukviarman menyatakan bahwa perspektif ini memberikan implikasi bahwa manajemen harus mempertimbangkan stakeholders di dalam membuat berbagai keputusan organisasi. Satu hal yang patut direnungkan adalah pernyataan seorang pengusaha Andrew Carnegie, ${ }^{32}$ bahwa filantropi atau karya amal merupakan kewajiban bagi semua orang kaya. Hal ini didasarkan pada pandangan pribadinya tentang hakikat dari kekayaan yang dikumpulkan oleh setiap pengusaha. Menurutnya kekayaan hanyalah trust fund atau dana yang dipercayakan kepada the haves untuk membantu orang-orang yang membutuhkannya.

Mengacu pada pernyataan-pernyataan dan pesan moral di atas, maka pelaksanaan Tanggung Jawab Sosial Perusahaan khususnya di Indonesia harus tetap didorong dan diperjuangkan. Menurut Wibisono, setidaknya terdapat tiga alasan penting mengapa kalangan dunia usaha harus merespon CSR agar sejalan dengan jaminan keberlanjutan operasional perusahaan, yaitu: ${ }^{33}$ Pertama, peru-

Bisnis. Jakarta: The Indonesian Institute for Corporate Governance, 2005, hlm. 27.

${ }^{32}$ Poerwanto. Budaya Perusahaan. Yogyakarta: Pustaka Pelajar, 2008, hlm. 172 menyatakan bahwa Carnegie memandang bahwa bisnis berperan untuk menggandakan kekayaan atau sumber-sumber milik masyarakat dan mengembalikan sebagian dari hasilnya untuk kepentingan masyarakat itu sendiri.

${ }^{33}$ Rahmatullah, CSR dan Kepentingan Pemerintah Daerah. http://rahmatullah. banten-institute.org/2011/05/csr-dan-kepentingan-pemerintah-daerah.html. Diakses 
sahaan adalah bagian dari masyarakat, oleh karenanya wajar bila perusahaan memperhatikan kepentingan masyarakat. Perusahaan harus menyadari bahwa mereka beroperasi dalam tatanan lingkungan masyarakat. Kegiatan sosial berfungsi sebagai kompensasi atau upaya imbal balik atas penguasaan sumber daya alam atau sumber daya ekonomi oleh perusahaan yang kadang bersifat ekspansif dan eksploratif.

Kedua, kalangan bisnis dan masyarakat sebaiknya memiliki 23 hubungan yang bersifat simbiosis mutualisme. Untuk mendapatkan dukungan dari masyarakat, wajar bila perusahaan dituntut untuk memberikan kontribusi positif kepada masyarakat, sehingga bisa tercipta harmonisasi hubungan bahkan pendongkrakan citra dan performa perusahaan.

Ketiga, kegiatan CSR merupakan salah satu cara untuk meredam atau bahkan menghindarkan konflik sosial. Potensi konflik itu bisa berasal akibat dari dampak operasional perusahaan atau akibat kesenjangan struktural dan ekonomis yang timbul antara masyarakat dengan komponen perusahaan.

Meskipun isu tanggung jawab sosial perusahaan sudah cukup lama muncul di negara-negara maju, akan tetapi isu tersebut masih cukup intens dibahas di negara Indonesia. ${ }^{34}$ Respons pemerintah terhadap pentingnya tanggung jawab sosial perusahaan ini terlihat dari dikeluarkannya kebijakan pemerintah melalui Keputusan Menteri BUMN Nomor Kep-236/MBU/2003 yang mengharuskan seluruh BUMN untuk menyisihkan sebagian labanya untuk pem-

tanggal 15 Januari 2012.

34 Badarudin, Implementasi Tanggung Jawab Sosial Perusahaan terhadap Masyarakat melalui Pemanfaatan Potensi Modal Sosial, Pidato Pengukuhan Jabatan Guru Besa Tetap dalam Bidang IImu Sosiologi Perkotaan pada Fakultas IImu Sosial Politik dan IImu Politik diucapkan di hadapan Rapat Terbuka Universitas Sumatera Utara pada 12 April 2008. 
berdayaan masyarakat yang dikenal dengan Program Kemitraan dan Bina Lingkungan (PKBL). Implementasinya dapat diketahui melalui Surat Edaran Menteri BUMN, SE Nomor 433/MBU/2003 yang merupakan petunjuk pelaksanaan dari keputusan menteri BUMN tersebut di atas.

Lebih lanjut, penerbitan Undang-Undang Nomor 40 Tahun 2007 tentang Perseroan Terbatas yang di dalamnya memuat ke24 wajiban perusahaan khususnya perusahaan yang mengeksplorasi sumber daya alam untuk melakukan tanggung jawab sosial perusahaan sebagaimana disebutkan dalam Pasal 74 sebagai berikut:

(1) Perseroan yang menjalankan kegiatan usahanya di bidang dan/ atau berkaitan dengan sumber daya alam wajib melaksanakan tanggung jawab sosial dan lingkungan.

(2) Tanggung jawab sosial dan lingkungan sebagaimana dimaksud pada ayat (1) merupakan kewajiban perseroan yang dianggarkan dan diperhitungkan sebagai biaya perseroan yang pelaksanaannya dilakukan dengan memperhatikan kepatutan dan kewajaran.

(3) Perseroan yang tidak melaksanakan kewajiban sebagaimana dimaksud pada ayat (1) dikenai sanksi sesuai dengan ketentuan peraturan perundang-undangan.

(4) Ketentuan lebih lanjut mengenai tanggung jawab sosial dan lingkungan diatur dengan Peraturan Pemerintah

Menyimak pengaturan yang diberikan dalam Undang-Undang Nomor 40 Tahun 2007 tentang Perseroan Terbatas, maka dapat disimpulkan beberapa hal antara lain:

a. tanggung jawab sosial perusahaan merupakan kewajiban bagi perseroan yang kegiatan usaha mengelola dan memanfaatkan sumber daya alam atau perseroan yang tidak mengelola dan 
tidak memanfaatkan sumber daya alam, tetapi kegiatan usahanya berdampak pada fungsi kemampuan sumber daya alam;

b. penyelenggaraan tanggung jawab sosial perusahaan dimasukkan sebagai biaya perseroan;

c. penyelenggaraan tanggung jawab sosial perusahaan memperhatikan prinsip kepatutan dan prinsip kewajaran;

d. terdapat sanksi apabila tanggung jawab sosial perusahaan tidak dilaksanakan dimana sanksi tersebut dikenakan berdasarkan 25 peraturan perundang-undangan yang terkait;

e. tanggung jawab sosial perusahaan didasarkan pada ide keseimbangan hubungan antara perseroan, lingkungan dan sosial.

Kemudian, pada tahun 2012 diterbitkan Peraturan Pemerintah Nomor 47 Tahun 2012 tentang Tanggung Jawab Sosial dan Lingkungan Perseroan Terbatas sebagai aturan pelaksana Pasal 74 ayat (4) Undang-Undang Nomor 40 Tahun 2007 tentang Perseroan Terbatas sebagaimana telah dipaparkan sebelumnya. Peraturan Pemerintah Nomor 47 Tahun 2012 tentang Tanggung Jawab Sosial dan Lingkungan Perseroan Terbatas menyatakan dalam Pasal 2 bahwa "Setiap perseroan selaku subjek hukum mempunyai tanggung jawab sosial dan lingkungan". Ketentuan ini menegaskan bahwa pada dasarnya setiap perseroan sebagai wujud kegiatan manusia dalam bidang usaha, secara moral mempunyai komitmen untuk bertanggung jawab atas terciptanya hubungan perseroan yang serasi dan seimbang dengan lingkungan dan masyarakat setempat sesuai dengan nilai, norma dan budaya masyarakat tersebut sehingga secara tidak langsung akan mendukung pembangunan masyarakat di daerah tersebut.

Polemik tentang apakah CSR itu bersifat wajib atau sukarela menggambarkan perdebatan klasik antara paradigma corporate vo- 
luntarism dan corporate involuntarism. Memang pada substansinya CSR merupakan tanggungjawab sosial yang bersifat sukarela. Namun "sukarela" disini tidak berarti perusahaan boleh untuk menghindar dari kewajiban sosial (CSR) tersebut. Dampak yang ditimbulkan oleh praktek bisnis perusahaan besar, terutama yang bergerak dalam industri ekstratif sumber daya alam, terhadap kelestarian alam dan lingkungan sekitar sangatlah luar biasa sehingga se26 tiap bentuk dampak negatif yang ditimbulkannya tidak bisa dipertanggungjawabkan hanya secara "sukarela". Dampak eksternalitas semacam ini, merupakan salah satu problem publik yang harus ditangani administrasi negara. Menurut Caiden tanggung jawab penanganan masalah eksternalitas menjadi salah satu tugas dalam fungsi manajemen ekonomi yang dijalankan administrasi negara. Jadi adanya CSR sesungguhnya tidak merubah secara substansial fungsi administrasi negara.

Selanjutnya dengan diwajibkannya CSR, maka yang perlu juga diperhatikan adalah kesan dan kekhawatiran dunia usaha bahwa UU tersebut akan menjadi legitimasi praktik pungutan liar karena peraturan itu mencakup kewajiban perusahaan untuk mengalokasikan dana CSR. ${ }^{35}$ Tantangan lainnya adalah dengan diberlakukannya UU No. 22 Tahun 1999 tentang Otonomi Daerah dikhawatirkan terjadinya: (a) egoisme daerah yang berlebihan yang akan membatasi ruang gerak koordinasi antar Kabupaten/Kota, padahal pengelolaan lingkungan selalu menuntut di luar batas administrasi karena ciri-ciri ekologisnya, (b) mendorong Pemerintah Kabupaten/Kota mengeksploitasi sebanyak-banyaknya SDA tanpa

35 Jackie Ambadar. CSR dalam Praktik di Indonesia. Jakarta: Elex Media Komputindo, 2008, hlm. 6. 
memperhatikan daya dukungnya demi mengejar PAD, ${ }^{36}$ (c) CSR dijadikan sebagai alat untuk meningkatkan PAD sehingga tujuan dari CSR tidak tercapai.

Sebenarnya perusahaan yang telah melaksanakan CSR juga memperoleh manfaat di dalamnya. Sebagaimana dinyatakan R. Edward Freeman ${ }^{37}$ apabila korporasi tidak memperhatikan stakeholders, seperti supplier, rekanan atau konsumen, maka pada giliran berikutnya mereka akan memperlakukan hal yang sama terhadap perusahaan, misalnya konsumen enggan membeli produknya dan supplier tidak menyetor bahan baku yang berkualitas untuk proses produksi korporasi.

Dari pemikiran inilah banyak pihak yang mengarahkan korporasi untuk melakukan CSR sebagai tindakan yang diatur oleh hukum. Friends of The Earth International (FoEi) adalah LSM yang bergerak di bidang lingkungan hidup berkampanye dengan keras bahwa sebaiknya CSR, sebagai hasil dari World Summit On Sustainable Development Comitments On Corporate Social Responsibility tersebut supaya efektif harus dirumuskan dalam suatu ketentuan hukum yang mengikat (legally binding) dalam bentuk corporate accountability.

Senada dengan pendapat di atas, Sonny Keraf dalam tulisannya Bisnis, Politik, dan Masyarakat ${ }^{38}$ mengingatkan akan pentingnya sistem sosial politik dalam perilaku bisnis. Dengan mengutip pendapat Aristoteles yang mengatakan bahwa dalam sistem yang buruk, orang yang baik dapat menjadi jahat, dan sebaliknya dalam sistem yang baik, orang yang jahat dapat menjadi baik. Tanpa ingin mengatakan bahwa yang paling penting adalah sistem sosial poli-

\footnotetext{
${ }^{36}$ Sudharto P. Hadi. Op. Cit., hlm. 63-64.

${ }^{37}$ Mukti Fajar. Op. Cit.,hlm. 100-101.

${ }^{38}$ Harian Kompas tanggal 16 Juli 1997.
} 
tik yang baik dan kondusif bagi praktik bisnis yang etis, tidak bisa disangkal bahwa sistem sosial politik merupakan faktor yang tidak kalah pentingnya dengan faktor perilaku individual.

Karena betapapun baiknya perilaku moral pelaku bisnis, sulit untuk bertahan dalam sistem yang cenderung mengangkangi etika dan moralitas. Dengan kata lain, yang juga penting adalah penciptaan sistem ekonomi politik yang sebisa mungkin memberi 28 rambu-rambu yang jelas dan tegas bagi praktik bisnis yang baik dan etis. Dalam rangka itu, yang dibutuhkan adalah aturan hukum di bidang bisnis dan ekonomi sebagai kristalisasi nilai moral masyarakat.

Pentingnya regulasi tentang CSR ini sebenarnya tidak terlepas dari keberadaan fungsi hukum itu sendiri. Iredell Jenkins ${ }^{39}$ melihat dari fungsi hukum untuk mengatur ketertiban masyarakat. Untuk itu perlu dipahami ranah apa saja yang masuk wilayah hukum dan mana yang tidak termasuk. Iredell Jenkins mengatakan bahwa wilayah hukum dapat dilihat dari dua rezim, yaitu: necessity (kebutuhan) dan possibility (kemungkinan).

Necessity adalah rezim yang digunakan untuk mendukung pembangunan manusia (buman development). Tanpa kondisi yang aman dan stabil pembangunan manusia tidak bisa dilakukan. Necessity juga dilakukan untuk merawat nilai-nilai yang tertanam dalam masyarakat untuk menghindari goncangan sosial (radical change).

Sementara possibility berfungsi menciptakan kebebasan, kesempatan dan kemajuan yang diperlukan, untuk menciptakan kesempurnaan kebaikan (absolute good), seperti menghindari eksploitasi, korupsi, kesewenang-wenangan dan ketidakpastian.

${ }^{39}$ Mukti Fajar. Op. Cit. hlm. 137-138. 
Possibility hadir sebagai upaya menciptakan keamanan dan keadilan. Jika rezim necessity dan possibility menghendaki aturan hukum, maka akan melahirkan tanggung jawab hukum. Konsep tanggung jawab hukum, baik perdata maupun pidana adalah suatu alat yang sangat penting untuk bekerjanya hukum secara efektif dalam masyarakat. Dalam konteks penerapan kewajiban hukum terhadap CSR ini, Mukti fajar sepakat dengan pendapat di atas yang mendasarkan pada rezim necessity dan possibility. Artinya kewajiban untuk CSR menjadi perlu ketika korporasi cenderung menghalangi pembangunan manusia dan berpeluang memunculkan eksploitasi, korupsi, kesewenang-wenangan dan ketidakpastian dalam masyarakat.

Pendapat lain tentang perlunya CSR diatur dengan regulasi dikemukakan oleh Veronica Besmer yang mendasarkan pada kekuatan berlakunya. Besmer menyatakan,$^{40}$ setidaknya ada dua alasan mengapa CSR harus diatur dalam hukum negara, yaitu: Pertama, bahwa tidak adanya kekuatan memaksa dari hukum kebiasaan atau sukarela, tanpa diratifikasi dalam peraturan lokal sebuah negara. Kedua, bahwa prinsip sukarela yang tidak mengikat, tidak akan memberikan efek apa pun secara jelas dan terukur. Pendapat ini tidak jauh berbeda dari apa yang dikatakan oleh Pablo Nieto. Dia menjelaskan alasan perlunya CSR diatur oleh hukum negara. Pertama, bahwa negara mempunyai peran untuk mengatur korporasi, dan kedua, pengaturan hukum diperlukan untuk memperjelas definisi tentang konsep CSR, ukuran pelaksanaan dan standarisasi dalam sistem audit.

40 Ibid. hlm. 104. 
Sementara itu Pall A. Davidsson, ${ }^{41}$ menyampaikan pandangan beberapa Negara Uni Eropa yang mendukung CSR dalam Legally Binding Standart, dengan argumen yang diajukan ialah:

a) Enbancement of Economic Integration

Aturan hukum akan memberikan standard yang jelas bagi semua korporasi untuk meningkatkan integrasi ekonomi dengan masyarakat.

b) Beyond Existing Global Efforts

Pendekatan sukarela (voluntary approach) mempunyai resiko membingungkan dan tumpang tindih dengan berbagai code of conduct yang dibuat oleh NGO, organisasi internasional maupun kelompok industri. Uni Eropa menekankan bahwa penerapan CSR secara hukum tetap diperlukan, walaupun menjadi suatu perihal yang unique dalam kajian normatif demi mendukung upaya-upaya global.

c) Efficiency

Salah satu alasan yang menjadi pendukung penerapan CSR secara hukum adalah isu efisiensi. Lembaga Amnesty International, Global Witness dan Kelompok Lingkungan Hidup World Wildlife Fund (WWF) menyatakan bahwa aturan yang mengikat akan bekerja lebih efisien dan meyakinkan secara sosial.

d) Governance

Pokok perhatian dari CSR adalah pemenuhan hak asasi manusia yang telah dinyatakan secara internasional. Di luar itu, CSR juga mendorong korporasi untuk bertanggung jawab pada lingkungan hidup dan masyarakat dimana mereka beroperasi. Untuk itu korporasi harus melakukan tata kelola yang baik untuk pihak internal maupun untuk pihak eksternal.

${ }^{41}$ Ibid. hlm. 106-109. 
Mosley salah seorang yang mendukung prinsip mandatory bagi pelaksanaan CSR, ia mengatakan: "Corporate social responsibility refers to managements obligation to set policies, make decisions and follow courses of action beyond the requirements of the law that are desirable in term of the values and objectives of society.

Pendapat ini juga didukung oleh Baker yang mengatakan: CSR is not philanthropy and it must be more than just obeying the law. Melihat situasi kondisi abad ke-21 ini, banyak hal buruk yang telah dilakukan oleh korporasi. Oleh karena itu, Larry Cata Backer mengutip pendapat Faley, menegaskan bahwa CSR dapat diasumsikan lebih tepatnya untuk ditempatkan dalam ranah hukum, kalau perlu dijadikan hukum yang sakral (fetish rule of law), supaya korporasi lebih mentaati CSR.

Selanjutnya Thomas McInerney memberikan beberapa argumentasi bahwa CSR sebaiknya diatur oleh hukum. Pertama, norma hukum memberikan proteksi yang lebih jelas dan terukur dari pada inisiatif sukarela. Kedua, walaupun isu CSR berdimensi internasional, tetapi korporasi secara praktis dikontrol oleh negara di mana korporasi itu beroperasi. Ketiga, program CSR yang berdasar kesukarelaan seringkali mengabaikan prioritas pembangunan dan perlindungan bagi warga negara. Keempat, bahwa hukum dari suatu negara yang seharusnya berperan dalam mengarahkan pembangunan ekonomi.

Sementara Anne T. Lawrence dan James Weber memberikan penjelasan yang lebih komprehensif tentang perlunya penerapan kewajiban hukum terhadap CSR. Mereka menyampaikan lima hal, yaitu: 
a) Balances Corporate Power with Responsibility

Korporasi besar dengan segala kekuasaannya kadang melupakan kepentingan sosial. Dengan aturan hukum yang ketat (iron law of responsibility) akan meningkatkan komitmen korporasi pada tanggung jawab sosial.

b) Discourages Goverment Regulation

Walaupun regulasi pemerintah akan berdampak pada kebebasan dalam pengambilan keputusan bisnis, namun hal ini dianggap lebih baik. Sebab akan mengarahkan kebebasan bisnis untuk mempertemukan antara sistem pasar dengan kepentingan sosial.

c) Promotes Long Term Profit for Business

CSR pada hakikatnya adalah salah satu bentuk investasi. Korporasi yang melakukannya akan mendapatkan keuntungan jangka panjang.

d) Improve Business Value and Reputation

Reputasi adalah salah satu hal penting bagi bisnis dalam membangun kepercayaan pada masyarakat. Saat ini, "reputation index" banyak dilakukan dengan memberikan penghargaan bagi korporasi yang melakukan CSR (CSR Award).

e) Corrects Social Problems Caused by Business

Pada kenyataannya, aktifitas bisnis korporasi telah memberikan dampak buruk bagi masyarakat, seperti pencemaran lingkungan. Kewajiban CSR adalah salah satu upaya untuk mencegah atau memulihkan kondisi buruk tersebut.

Masih kuatnya pendapat klasik yang mengatakan bahwa CSR sesungguhnya adalah kewajiban moral, bukannya kewajiban hukum menjadi hambatan bagi regulasi CSR. Sebenarnya antara moral dan hukum adalah dua hal yang tidak dapat dipisahkan. 
John Stuart Mills ${ }^{42}$ mengatakan bahwa keadilan sebagai cita hukum harus didasarkan pada nilai moral. Justice is a name for certain moral requirement, which, regarded collectively, stand higher in the scale of social utility, and therefore of more paramount obligation, than any others. Ada tiga prinsip dasar moral, yaitu: yang hak (right), yang wajib (obligation), dan yang baik (the good).

Hans Kelsen sendiri meletakkan keadilan dalam kerangka kewajiban moral normatif dan untuk itulah hukum harus ditaati. Dari berbagai argumentasi di atas, bahwa pelaksanaan CSR yang berdasarkan prinsip sukarela (voluntary) atas pertimbangan etika bisnis, dapat kiranya dialihkan kedalam prinsip kewajiban (mandatory). Sebab sudah seharusnya kewajiban hukum dibangun berdasarkan nilai-nilai moral. Untuk itu tidak perlu diperdebatkan lagi. Sebab antara hukum dan moral tidak dapat dilepaskan satu sama lain.

Apabila secara teori dan filosofis CSR sebagai kewajiban moral dapat dialih kepada kewajiban hukum, maka persoalan selanjutnya adalah mengenai pengaturan dalam peraturan perundangundangan. Menurut Cynthia A. Williams ada keterbatasan hukum untuk mengarahkan CSR masuk ke ranah hukum. Selain itu, Pall A. Davidsson mengatakan bahwa isu-isu CSR telah masuk pada level internasional, sehingga menuntut konsekuensi pada legitimasi dan penegakan hukum. 


\section{BAGIAN III \\ Landasan Filosofis, Yuridis dan Yuridis Pengaturan CSR}

\section{A. Landasan Filosofis}

Suatu norma hukum dikatakan berlaku secara filosofis apabila norma hukum itu memang bersesuaian dengan nilai-nilai filosofis yang dianut dalam negara tersebut yang tidak lain berisi nilai-nilai moral dan etika sebagai rujukan dalam membentuk hukum yang akan dipengaruhi dalam kehidupan bangsa tersebut.

Seperti halnya dalam pandangan Hans Kelsen mengenai grundnorm atau dalam pandangan Hans Nawiasky tentang staatsfundamentalnorm bahwa pada setiap negara selalu ditentukan adanya nilainilai dasar atau nilai-nilai filosofis tertinggi yang diyakini sebagai sumber dari segala sumber nilai luhur dalam kehidupan kenegaraan yang bersangkutan. ${ }^{43}$

Landasan filosofis adalah filsafat atau pandangan atau ide yang menjadi dasar cita-cita sewaktu menuangkan hasrat dan kebijaksanaan ke dalam rencana atau draf peraturan negara. ${ }^{44}$ Jimly dalam hal ini juga berpendapat bahwa landasan filosofis yaitu bahwa undang-undang selalu mengandung norma-norma hukum yang diidealkan (ideal norms) oleh suatu masyarakat ke arah mana citacita luhur kehidupan bermasyarakat dan bernegara hendak diarah-

${ }^{43}$ Jimly Asshiddiqie, Perihal... Loc. Cit., hal. 166.

${ }^{44}$ Solly Lubis, Landasan dan Teknik Perundang-undangan, PT. Mandar Maju, Bandung, 1995, hal. 8. 
kan. Dalam hal ini, nilai-nilai filosofis negara Republik Indonesia terkandung dalam Pancasila sebagai staatsfundamentalnorm dan Undang-Undang Dasar 1945 yang dicerminkan dalam bentuk peraturan perundang-undangan.

Sesuai dengan amanat UUDNRI 1945 dan Pancasila, penyelenggaraan pemerintahan negara didasarkan dan diatur menurut ketentuan-ketentuan konstitusi, maupun ketentuan hukum lainnya, yaitu undang-undang, peraturan pemerintah, peraturan daerah, maupun ketentuan-ketentuan hukum lainnya yang ditentukan secara demokratis dan konstitusional. ${ }^{45}$

Hal ini mengandung makna bahwa penyelenggaraan pemerintahan negara dilakukan melalui berbagai kebijakan pemerintahan negara senantiasa didasarkan dan dicernakan melalui ketetapanketetapan hukum yang dikelola secara demokratis. Penyelenggaraan negara yang demokratis dilaksanakan dengan mengutamakan keseimbangan antara tugas, wewenang, tanggung jawab, dan kewajiban, dalam mengurus dan menjalankan pemerintahan. Secara teoritis sistem pemerintahan ini dikenal dengan sistem desentralisasi, yang mengandung dua unsur pokok yaitu terbentuknya daerah otonom dan otonomi daerah.

Pemerintahan Daerah dapat mengatur dan mengurus sendiri urusan pemerintahannya sesuai dengan asas otonomi dan tugas pembantuan, yang ditujukan untuk mencapai kesejahteraan masyarakat, melalui peningkatan, pelayanan, pemberdayaan dan peran serta masyarakat, serta peningkatan daya saing daerah dengan memperhatikan prinsip-prinsip demokrasi, pemerataan, keadilan, dan kekhususan daerah dalam sistem Negara Kesatuan

45 Surachmin, 225 Asas Dan Prinsip Hukum Serta Penyelenggaraan Negara, Yayasan Gema Yustisia Indonesia, Jakarta, h. 14 - 15. 
Republik Indonesia. ${ }^{46}$

Filosofi pengaturan tentang Tanggung Jawab Sosial Perusahaan di daerah sendiri dimaksud untuk memberikan kepastian dan perlindungan hukum atas penyelenggaraan program tanggung jawab sosial perusahaan serta memberikan arahan kepada kepada semua perusahaan dan semua pemangku kepentingan atas penyelenggaraan program tanggung jawab sosial perusahaan tersebut.

\section{B. Landasan Sosiologis}

Pandangan sosiologis mengenai keberlakuan suatu peraturan perundang-undangan cenderung lebih mengutamakan pendekatan yang empiris dengan mengutamakan beberapa pilihan kriteria, yaitu: ${ }^{47}$

a) Kriteria pengakuan (recognition theory) menyangkut sejauh mana subjek hukum yang diatur memang mengakui keberadaan dan daya ikat serta kewajibannya untuk menundukkan diri terhadap norma hukum yang bersangkutan. Jika subjek hukum yang bersangkutan tidak merasa terikat, maka secara sosiologis norma hukum yang bersangkutan tidak dapat dikatakan berlaku baginya.

b) Kriteria faktisitas hukum dengan menekankan pada kenyataan sejauh mana norma hukum itu sendiri memang sungguhsungguh berlaku efektif dalam kehidupan nyata masyarakat. Meskipun suatu norma hukum secara yuridis formal memang berlaku, diakui (recognized), dan diterima (received) oleh masyarakat sebagai sesuatu yang memang ada (exist) dan ber-

${ }^{46} \mathrm{HAW}$. Widjaya, Penyelenggaraan Otonomi Di Indonesia Dalam Rangka Sosialisasi UU No.32 Tahun 2004 Tentang Pemerintahan Daerah, RajaGrafindo Persada, Jakarta, 2005, h.131.

47 Jimly Asshiddiqie, Perihal...Op.Cit., hal. 168. 
laku (valid), tetapi dalam kenyataan praktiknya sama sekali tidak efektif, berarti dalam faktanya norma hukum itu tidak berlaku. Oleh karena itu, suatu norma hukum baru dapat berlaku menurut salah satu kriteria tersebut.

Kriteria faktisitas hukum menekankan pada sejauh mana norma hukum ataupun pasal yang dimuat di dalamnya memang sungguh-sungguh berlaku efektif dalam kehidupan nyata masyarakat. Meskipun suatu norma hukum secara yuridis formal memang berlaku, diakui dan diterima oleh masyarakat sebagai sesuatu yang memang ada dan berlaku, tetapi dalam kenyataan praktiknya sama sekali tidak efektif, berarti dalam faktanya norma hukum itu tidak berlaku. Oleh karena itu, suatu norma hukum baru dapat berlaku menurut salah satu kriteria tersebut.

Setiap norma hukum yang dituangkan dalam bentuk peraturan perundang-undangan harus mencerminkan tuntutan kebutuhan masyarakat, yang berarti bahwa hukum yang dibentuk harus sesuai dengan hukum yang hidup (the living law) dalam masyarakat. Suatu peraturan perundang-undangan dikatakan mempunyai landasan sosiologis apabila ketentuan-ketentuannya sesuai dengan keyakinan masyarakat akan hukum, baik tata nilai maupun hukum yang hidup dalam masyarakat.

\section{Landasan Yuridis}

Keberlakuan yuridis adalah keberlakuan suatu norma hukum dengan daya ikatnya untuk umum sebagai suatu dogma yang dilihat dari pertimbangan yang bersifat teknis yuridis sebagaimana: ${ }^{48}$

a. ditetapkan sebagai norma hukum berdasarkan norma hukum yang lebih superior atau yang lebih tinggi,

\section{Ibid.}


b. ditetapkan mengikat atau berlaku karena menunjukkan hubungan keharusan antara suatu kondisi dengan akibatnya,

c. ditetapkan sebagai norma hukum menurut prosedur pembentukan hukum yang berlaku,

d. ditetapkan sebagai norma hukum oleh lembaga yang memang berwenang untuk itu.

e. Jika keempat kriteria tersebut telah terpenuhi sebagaimana mestinya, maka norma hukum yang bersangkutan dapat dikatakan memang berlaku secara yuridis, baik dari segi formil dengan memberi kewenangan bagi instansi tertentu untuk membuat peraturan tertentu maupun dari segi materil sebagai dasar hukum untuk mengatur hal-hal tertentu.

Dengan demikian, untuk menjamin kepastian hukum, perlindungan hukum dan rasa keadilan masyarakat serta menghindari tumpang tindih peraturan pengaturan tentang Tanggung Jawab Sosial Perusahaan, di daerah sendiri menggunakan landasan yuridis, sebagai berikut:

1. Undang-Undang Dasar Negara Kesatuan Republik Indonesia Tahun 1945 (UUD 1945);

2. Undang-Undang Nomor 22 Tahun 2001 tentang Minyak dan Gas Bumi (Lembaran Negara Republik Indonesia Nomor 136 Tahun 2001, Tambahan Lembaran Negara Republik Indonesia Nomor 4152);

3. Undang-Undang Nomor 19 Tahun 2003 Tentang Badan Usaha Milik Negara (Lembaran Negara Republik Indonesia Nomor 70 Tahun 2003, Tambahan Lembaran Negara Republik Indonesia Nomor 4297);

4. Undang-Undang Nomor 25 Tahun 2007 tentang Penanaman Modal (Lembaran Negara Republik Indonesia Nomor 67 
Tahun 2007, Tambahan Lembaran Negara Republik Indonesia Nomor 4724);

5. Undang-Undang Nomor 40 Tahun 2007 tentang Perseroan Terbatas (Lembaran Negara Republik Indonesia Nomor 106 Tahun 2007, Tambahan Lembaran Negara Republik Indonesia Nomor 4756);

6. Undang-Undang Nomor 4 Tahun 2009 tentang Pertambangan Mineral dan Batubara (Lembaran Negara Republik Indonesia

Nomor 4 Tahun 2009, Tambahan Lembaran Negara Republik Indonesia Nomor 4959);

7. Undang-Undang Nomor 32 Tahun 2009 tentang Perlindungan dan Pengelolaan Lingkungan Hidup (Lembaran Negara Republik Indonesia Nomor 140 Tahun 2009, Tambahan Lembaran Negara Republik Indonesia Nomor 5059);

8. Undang-Undang Nomor 12 Tahun 2011 tentang Pembentukan Peraturan Perundang-undangan (Lembaran Negara Republik Indonesia Nomor 82 Tahun 2011, Tambahan Lembaran Negara Republik Indonesia Nomor 5234)

9. Undang-Undang Nomor 21 Tahun 2014 tentang Panas Bumi (Lembaran Negara Republik Indonesia Nomor 217 Tahun 2014, Tambahan Lembaran Negara Republik Indonesia Nomor 5585)

10. Undang-Undang Nomor 2 Tahun 2015 tentang Penetapan Peraturan Pemerintah Pengganti Undang-Undang Nomor 2 Tahun 2014 tentang Perubahan Atas Undang-Undang Nomor 23 Tahun 2014 tentang Pemerintahan Daerah (Lembaran Negara Republik Indonesia Nomor 244 Tahun 2014, Tambahan Lembaran Negara Republik Indonesia Nomor 5587) menjadi Undang-Undang (Lembaran Negara Republik Indonesia 
Tahun 2015 Nomor 24, Tambahan Lembaran Negara Republik Indonesia Nomor 5657);

11. Peraturan PemerintahNomor38Tahun2007 tentang Pembagian Urusan Pemerintahan antara Pemerintah, Pemerintah Daerah Provinsi dan Pemerintah Kabupaten/Kota (Lembaran Negara Republik Indonesia Nomor 82 Tahun 2007, Tambahan Lembaran Negara Republik Indonesia Nomor 4737);

40 12. Peraturan Pemerintah Nomor 47 Tahun 2012 tentang Tanggung Jawab Sosial dan Lingkungan Perseroan Terbatas (Lembaran Negara Republik Indonesia Nomor 89 Tahun 2012, Tambahan Lembaran Negara Republik Indonesia Nomor 5305);

13. Peraturan Menteri Badan Usaha Milik Negara Nomor PER-05/ MBU/2007 tentang Program Kemitraan Badan Usaha Milik Negara dengan Usaha Kecil dan Program Bina Lingkungan sebagaimana terakhir diubah dengan Peraturan Menteri Badan Usaha Milik Negara Nomor 8 Tahun 2013 tentang Perubahan Keempat Atas Peraturan Menteri Negara Badan Usaha Milik Negara Nomor 5 Tahun 2007 tentang Program Kemitraan Badan Usaha Milik Negara dengan Usaha Kecil dan Program Bina Lingkungan; 


\section{BAGIAN IV \\ Analisis Peraturan Perundang- Undangan Terkait CSR}

K

ajian terhadap peraturan perundang-undangan ini dimak-

sudkan untuk mengetahui kondisi hukum atau peraturan perundang-undangan yang mengatur mengenai substansi atau materi yang akan diatur. Dalam kajian ini akan diketahui posisi dari peraturan daerah yang baru. Analisis ini akan menggambarkan sinkronisasi, harmonisasi peraturan perundang-undangan yang ada serta posisi dari peraturan daerah untuk menghindari terjadinya tumpang tindih pengaturan.

Saat ini ada beberapa aturan hukum baik yang secara tegas atau eksplisit maupun yang implisit yang mewajibkan perusahaan tertentu melaksanakan aktivitas CSR atau tanggung jawab sosial dan lingkungan, serta satu panduan (guidance) internasional mengenai tanggungjawab berkelanjutan (sustainability responsibility), diantaranya: ${ }^{49}$

\section{Undang-Undang Nomor 5 Tahun 1990 Tentang}

Konservasi Sumber Daya Alam Hayati Dan

\section{Ekosistemnya}

Sumber daya alam hayati Indonesia dan ekosistemnya yang mempunyai kedudukan serta peranan penting bagi kehidu-

\footnotetext{
${ }^{49}$ Rahmatullah. Loc. Cit.
} 
pan manusia, oleh karena itu perlu dikelola sebaik-baiknya bagi kesejahteraan masyarakat Indonesia baik untuk masa kini maupun untuk masa depan. Pasal 9 ayat (1) menyatakan: "Setiap pemegang hak atas tanah dan hak pengusahaan di perairan dalam wilayah sistem penyangga kehidupan wajib menjaga kelangsungan fungsi perlindungan wilayah tersebut".

Sedangkan ayat (2) menyatakan: "Dalam rangka pelaksanaan

42 perlindungan sistem penyangga kehidupan, Pemerintah mengatur serta melakukan tindakan penertiban terhadap penggunaan dan pengelolaan tanah dan hak pengusahaan di perairan yang terletak dalam wilayah perlindungan sistem penyangga kehidupan sebagaimana dimaksud pada Pasal 8".

Berdasarkan ketentuan di atas, maka Pemerintah Daerah berhak untuk mengatur dan melakukan tindakan pada setiap pemegang hak atas tanah dan hak pengusahaan di perairan termasuk di dalamnya badan usaha atau perusahaan dengan mewajibkan untuk menjaga kelangsungan fungsi perlindungan wilayah. Kewajiban ini dimaksudkan agar sumber daya alam hayati dan ekosistemnya dapat dimanfaatkan untuk kesejahteraan seluruh masyarakat Indonesia. Atas dasar ini Pemerintah Daerah berhak mengatur keberadaan suatu perusahaan untuk ikut memberikan kontribusinya di dalam mensejahterakan masyarakat melalui program TSP-nya.

\section{Undang-Undang Nomor 30 tahun 1999 tentang Arbitrase dan Alternatif Penyelesaian Sengketa}

Sebagaimana dinyatakan di dalam Pasal 2 bahwa Undangundang ini mengatur penyelesaian sengketa atau beda pendapat antar para pihak dalam suatu hubungan hukum tertentu yang te- 
lah mengadakan perjanjian arbitrase yang secara tegas menyatakan bahwa semua sengketa atau beda pendapat yang timbul atau yang mungkin timbul dari hubungan hukum tersebut akan diselesaikan dengan cara arbitrase atau melalui alternatif penyelesaian sengketa.

Sementara itu Pasal 4 menyatakan:

(1) Dalam hal para pihak telah menyetujui bahwa sengketa di antara mereka akan diselesaikan melalui arbitrase dan para pihak telah memberikan wewenang, maka arbiter berwenang menentukan dalam putusannya mengenai hak dan kewajiban para pihak jika hal ini diatur dalam perjanjian mereka.

(2) Persetujuan untuk menyelesaikan sengketa melalui arbitrase sebagaimana dimaksud dalam ayat (1) dimuat dalam suatu dokumen yang ditandatangani oleh para pihak.

Pasal 7 menyatakan bahwa para pihak dapat menyetujui suatu sengketa yang terjadi atau yang akan terjadi antara mereka untuk diselesaikan melalui arbitrase. Berdasarkan ketentuan-ketentuan di atas, maka dalam hal terjadi sengketa atau perselisihan pendapat di dalam pelaksanaan atau implementasi TSP, para pihak dapat dapat menyelesaikannya dengan menggunakan lembaga arbitrase sepanjang di dalam perjanjian arbitrase secara tegas menyatakan bahwa sengketa atau beda pendapat tersebut akan diselesaikan dengan cara arbitrase atau melalui alternatif penyelesaian sengketa.

\section{Undang-Undang Nomor 41 tahun 1999 tentang Kehutanan}

Di dalam Undang-undang Kehutanan ketentuan yang terkait dengan TSP diatur khususnya pada Pasal 30, 32, 48 ayat (3), dan 50 ayat (2). 
Pasal 30: Dalam rangka pemberdayaan ekonomi masyarakat, setiap badan usaha milik negara, badan usaha milik daerah, dan badan usaha milik swasta Indonesia yang memperoleh izin usaha pemanfaatan jasa lingkungan, izin usaha pemanfaatan hasil hutan kayu dan bukan kayu, diwajibkan bekerja sama dengan koperasi masyarakat setempat.

Pasal 32: Pemegang izin sebagaimana diatur dalam Pasal 27

44 dan Pasal 29 berkewajiban untuk menjaga, memelihara, dan melestarikan hutan tempat usahanya.

Pasal 48 ayat (3): Pemegang izin usaha pemanfaatan hutan sebagaimana dimaksud dalam Pasal 27 dan Pasal 29, serta pihakpihak yang menerima wewenang pengelolaan hutan sebagaimana dimaksud dalam Pasal 34, diwajibkan melindungi hutan dalam areal kerjanya.

Pasal 50 ayat (2): Setiap orang yang diberikan izin usaha pemanfaatan kawasan, izin usaha pemanfaatan jasa lingkungan, izin usaha pemanfaatan hasil hutan kayu dan bukan kayu, serta izin pemungutan hasil hutan kayu dan bukan kayu, dilarang melakukan kegiatan yang menimbulkan kerusakan hutan.

\section{Undang-Undang Nomor 22 Tahun 2001 tentang Minyak dan Gas Bumi}

Senada dengan ketentuan-ketentuan di atas, Undang-Undang tentang Minyak dan Gas Bumi juga mengatur mengenai kewajiban untuk memperhatikan masalah lingkungan hidup khususnya pada Pasal 13 ayat (3) huruf p, dan Pasal 40 ayat (2), (3), dan ayat (5). Pasal 13 ayat (3) huruf p, menyebutkan bahwa: 'Kontrak Kerja Sama sebagaimana dimaksud dalam ayat (1) wajib memuat paling sedikit ketentuan-ketentuan pokok yaitu : (p). pengembangan masyarakat 
sekitarnya dan jaminan hak-hak masyarakat adat". Jadi berdasarkan Undang-undang tersebut, perusahaan yang operasionalnya terkait Minyak dan Gas Bumi baik pengelola eksplorasi maupun distribusi, wajib melaksanakan kegiatan pengembangan masyarakat dan menjamin hak-hak masyarakat adat yang berada di sekitar perusahaan.

Pasal 40 ayat (2) Undang-Undang Minyak dan gas Bumi: Badan Usaha atau Bentuk Usaha Tetap menjamin keselamatan dan kesehatan kerja serta pengelolaan lingkungan hidup dan menaati ketentuan peraturan perundangan-undangan yang berlaku dalam kegiatan usaha Minyak dan Gas Bumi.

Pasal 40 ayat (3) Pengelolaan lingkungan hidup sebagaimana dimaksud dalam ayat (2) berupa kewajiban untuk melakukan pencegahan dan penanggulangan pencemaran serta pemulihan atas terjadinya kerusakan lingkungan hidup, termasuk kewajiban pascaoperasi pertambangan.

Pasal 40 ayat (5) Badan Usaha atau Bentuk Usaha Tetap yang melaksanakan kegiatan usaha Minyak dan Gas Bumi sebagaimana dimaksud dalam Pasal 5 ikut bertanggung jawab dalam mengembangkan lingkungan dan masyarakat setempat.

\section{Undang-Undang Nomor 19 Tahun 2003 tentang Badan Usaha Milik Negara}

Badan Usaha Milik Negara (BUMN) mempunyai peranan penting dalam penyelenggaraan perekonomian nasional guna mewujudkan kesejahteraan masyarakat. Dalam UU BUMN di atas dinyatakan bahwa selain mencari keuntungan, peran BUMN adalah juga memberikan bimbingan bantuan secara aktif kepada pengusaha golongan lemah, koperasi dan masyarakat. Di sini BUMN wajib melaknasakan Program Kemitraan dan Bina Lingkungan 
(PKBL). Dasar dari PKBL diatur di dalam Pasal 88 yang menyatakan bahwa BUMN dapat menyisihkan sebagian laba bersihnya untuk keperluan pembinaan usaha kecil/koperasi serta pembinaan masyarakat sekitar BUMN.

Program Kemitraan BUMN dengan Usaha Kecil adalah program untuk meningkatkan kemampuan usaha kecil agar menjadi tangguh dan mandiri melalui pemanfaatan dana dari bagian

46 laba BUMN. Sedangkan Program Bina Lingkungan adalah program pemberdayaan kondisi sosial masyarakat oleh BUMN melalui pemanfaatan dana dari bagian laba BUMN. Jadi, bila dilihat dari dampak yang diharapkan timbul melalui Program Kemitraan maupun Bina Lingkungan, terlihat ada kesamaan dengan program CSR atau TSP perusahaan. Dampak tersebut adalah adanya peningkatan kesejahteraan dan pemberdayaan komunitas setempat yakni di wilayah di mana perusahaan atau BUMN berdomisili atau menjalankan aktivitas operasionalnya.

\section{Undang-Undang Nomor 7 Tahun 2004 tentang Sumber Daya Air}

Undang-undang ini juga mewajibkan perusahaan untuk ikut meningkatkan kepedulian pada masyarakat setempat. Ketentuan yang terkait dengan masalah tersebut diatur khususnya pada Pasal 47 ayat (3), 52, dan 83.

Pasal 47 ayat (3): Badan usaha dan perseorangan sebagaimana dimaksud pada ayat (1) wajib ikut serta melakukan kegiatan konservasi sumber daya air dan meningkatkan kesejahteraan masyarakat di sekitarnya.

Pasal 52: Setiap orang atau badan usaha dilarang melakukan kegiatan yang dapat mengakibatkan terjadinya daya rusak air. 
Pasal 83: Dalam menggunakan hak guna air, masyarakat pemegang hak guna air berkewajiban memperhatikan kepentingan umum yang diwujudkan melalui perannya dalam konservasi sumber daya air serta perlindungan dan pengamanan prasarana sumber daya air.

\section{Undang-Undang Nomor 32 Tahun 2004 tentang Pemerintahan Daerah}

Dalam Pasal 1 (5) UU No. 32 Tahun 2004 dinyatakan bahwa otonomi daerah adalah hak, wewenang, dan kewajiban daerah otonom untuk mengatur dan mengurus sendiri urusan pemerintahan dan kepentingan masyarakat setempat sesuai dengan peraturan perundang-undangan.

Dalam Pasal 1 (6) dinyatakan bahwa daerah otonom, selanjutnya disebut daerah, adalah kesatuan masyarakat hukum yang mempunyai batas-batas wilayah yang berwenang mengatur dan mengurus urusan pemerintahan dan kepentingan masyarakat setempat menurut prakarsa sendiri berdasarkan aspirasi masyarakat dalam sistem Negara Kesatuan Republik Indonesia.

Dalam Pasal 1(7) dinyatakan bahwa desentralisasi adalah penyerahan wewenang pemerintahan oleh Pemerintah kepada daerah otonom untuk mengatur dan mengurus urusan pemerintahan dalam sistem Negara Kesatuan Republik Indonesia. Berdasarkan ketentuan di atas, maka pemerintah daerah dapat melakukan pengaturan untuk menata praktik CSR agar lebih partisipatif, transparan dan akuntabel guna meningkatkan pelaksanaan pembangunan di daerah. 


\section{Undang-Undang Nomor 25 Tahun 2007 tentang Penanaman Modal}

Bagi penanaman modal asing, diatur dalam Undang-Undang Nomor 25 Tahun 2007 tentang Penanaman Modal, dalam Pasal 15 (b) dinyatakan bahwa "Setiap penanam modal berkewajiban melaksanakan tanggung jawab sosial perusahaan". Badan-Badan Usaha tersebut wajib melakukan CSR karena Pasal 34 Undang-

48 Undang Republik Indonesia Nomor 25 Tahun 2007 Tentang Penanaman Modal menyatakan:

(1) Badan usaha atau usaha perseorangan sebagaimana dimaksud dalam Pasal 5 yang tidak memenuhi kewajiban sebagaimana ditentukan dalam Pasal 15 dapat dikenai sanksi administratif berupa:

a. peringatan tertulis;

b. pembatasan kegiatan usaha;

c. pembekuan kegiatan usaha dan/atau fasilitas penanaman modal; atau

d. pencabutan kegiatan usaha dan/atau fasilitas penanaman modal.

(2) Sanksi administratif sebagaimana dimaksud pada ayat (1) diberikan oleh instansi atau lembaga yang berwenang sesuai dengan ketentuan peraturan perundang-undangan.

(3) Selain dikenai sanksi administratif, badan usaha atau usaha perseorangan dapat dikenai sanksi lainnya sesuai dengan ketentuan peraturan perundang-undangan.

Uraian Pasal 34 tersebut, sangat jelas bahwa Badan Usaha yang diatur sesuai dengan ketentuan Pasal 5 Undang-Undang Republik Indonesia Nomor 25 Tahun 2007 Tentang Penanaman Modal wajib melakukan CSR, jika badan usaha tersebut melanggar maka 
dikenai sanksi administratif selain itu dapat juga dikenai sanksi lainnya sesuai dengan ketentuan peraturan perundangan-undangan.

Dari pemberian sanksi tersebut dapat dimaknai bahwa bagi Badan Usaha yang tidak melaksanakan CSR (yang dahulu berbentuk voluntary) yaitu: melakukan tindakan etis, walaupun hal itu belum diatur oleh regulasi dan perilaku etis berupa pemberian dampak positif pada masyarakat dengan cara melakukan Community Development ataupun kegiatan karikatif (charity) akan dikenai sanksi administrasi sesuai dengan Pasal 34 ayat (1) dan (2) UndangUndang Republik Indonesia Nomor 25 Tahun 2007 Tentang Penanaman Modal. Dan bagi badan usaha yang tidak melaksanakan CSR dalam pengertian kepatuhan pada hukum (mandatory) maka akan dikenai sanksi sesuai ketentuan peraturan perundangundangan..$^{50}$

Meskipun UU ini telah mengatur sanksi-sanksi secara terperinci terhadap badan usaha atau usaha perseorangan yang mengabaikan CSR (Pasal 34), UU ini baru mampu menjangkau investor asing dan belum mengatur secara tegas perihal CSR bagi perusahaan nasional.

Berdasarkan uraian di atas, kini Tanggung jawab Sosial Perusahaan/ Tanggung jawab sosial dan Lingkungan (Corporate Social Responsibility) yang dulu terdiri dari sifat mandatory dan voluntary, setelah di berlakukannya Undang-Undang Republik Indonesia Nomor 25 Tahun 2007 Tentang Penanaman Modal dan UndangUndang Nomor 40 Tahun 2007 Tentang Perseroan Terbatas berubah menjadi hanya bersifat mandatory. Hal ini bukan sekedar

50 Trisoko S. Pengaturan CSR (Corporate Social Responsibility) di Indonesia,. http://breath4 justice.wordpress.com/2011/04/17/pengaturan-csr-corporate-socialresponsibility-di-indonesia/ Diakses tanggal 19 Januari 2012 
tranpartasi, maupun adopsi konsep CSR, tetapi merupakan bentuk inovasi dari pengaturan Corporate Social Responsibility.

\section{Undang-Undang Nomor 40 Tahun 2007 tentang Perseroan Terbatas}

Bagi Perseroan Terbatas (PT) yang mengelola Sumber Daya Alam (SDA) diwajibkan melaksanakan tanggungjawab sosial dan lingkungan, karena telah diatur dalam UU Perseroan Terbatas No.40 Tahun 2007. Dimana dalam Pasal 74 diatur bahwa : (1) Perseroan yang menjalankan kegiatan usahanya di bidang dan/atau berkaitan dengan sumber daya alam wajib melaksanakan Tanggung Jawab Sosial dan Lingkungan, (2) Tanggung Jawab Sosial dan Lingkungan sebagaimana dimaksud ayat (1) merupakan kewajiban Perseroan yang dianggarkan dan diperhitungkan sebagai biaya Perseroan yang pelaksanaannya dilakukan dengan memperhatikan kepatutan dan kewajaran, (3) Perseroan yang tidak melaksanakan kewajiban sebagaimana dimaksud pada ayat (1) dikenai sanksi sesuai dengan ketentuan peraturan perundang-undangan, (4) Ketentuan lebih lanjut mengenai Tanggung Jawab Sosial dan Lingkungan diatur dengan Peraturan Pemerintah.

UU PT tidak menyebutkan secara rinci berapa besaran biaya yang harus dikeluarkan perusahaan untuk CSR serta sanksi bagi yang melanggar. Pada Pasal 74 ayat (2), (3) dan (4) hanya disebutkan bahwa CSR "dianggarkan dan diperhitungkan sebagai biaya perseroan yang pelaksanaannya dilakukan dengan memperhatikan kepatutan dan kewajaran". PT yang tidak melakukan CSR dikenakan sanksi sesuai dengan peraturan dan perundangundangan. Ketentuan lebih lanjut mengenai CSR ini baru akan 
diatur oleh Peraturan Pemerintah, yang hingga kini belum dikeluarkan. ${ }^{51}$

Keberlakuan Pasal 74 UU PT tersebut terkait dengan Putusan Mahkamah Konstitusi Nomor 53/PUU-VI/2008 yang menolak permohonan uji materiil dengan menyatakan bahwa Pasal 74 UU PT tidak bertentangan dengan Pasal 28D ayat (1) jo Pasal 28I ayat (2) jo Pasal 33 ayat (4) UUD 1945. Dikatakan oleh para hakim MK bahwa, menjadikan TSP sebagai suatu kewajiban hukum melalui rumusan Pasal 74 merupakan kebijakan hukum dari pembentuk UU untuk mengatur dan menerapkan TSP dengan suatu sanksi, dan hal ini adalah benar, karena: ${ }^{52}$

a. Secara faktual, kondisi sosial dan lingkungan telah rusak di masa lalu ketika perusahaan mengabaikan aspek sosial dan lingkungan sehingga merugikan masyarakat sekitar dan lingkungan pada umumnya.

b. Budaya hukum di Indonesia tidak sama dengan budaya hukum negara lain, utamanya negara industri maju tempat konsep CSR pertama kali diperkenalkan di mana CSR bukan hanya merupakan tuntutan bagi perusahaan kepada masyarakat dan lingkungannya tetapi juga telah dijadikan sebagai salah satu indikator kinerja perusahaan dan syarat bagi perusahaan yang akan go public. Dengan kata lain, MK tampaknya berpendapat bahwa sesuai kultur hukum Indonesia, penormaan TSP sebagai norma hukum yang diancam dengan sanksi hu-

\footnotetext{
${ }^{51}$ Edi Suharto, Menggagas Standar Audit Program CSR Initiating Audit Standard of CSR Program. http://www.policy.hu/suharto/Naskah\%20PDF/CSRAudit.pdf Diakses Tanggal 13 Oktober 2011.

${ }^{52}$ A.F. Elly Erawaty, Persoalan Hukum Seputar Tanggung Jawab Sosial dan Lingkungan Perseroan dalam Perundang-Undangan Ekonomi Indonesia. http:// saepudinonline.wordpress.com/2011/04/11/persoalan-hukum-seputar-tanggungjawab-sosial-dan-lingkungan-perseroan-dalam-perundang-undangan-ekonomiindonesia/ Diakses tanggal 16 Januari 2012.
} 
kum merupakan suatu keharusan demi tegaknya TSP atau CSR.

c. Menjadikan TSP sebagai kewajiban hukum dinilai oleh MK justru untuk memberikan kepastian hukum sebab dapat menghindari terjadinya penafsiran yang berbeda-beda tentang TSP oleh perseroan sebagaimana dapat terjadi bila TSP dibiarkan bersifat sukarela. Hanya dengan cara memaksa tersebut akan dapat diharapkan adanya kontribusi perusahaan untuk ikut meningkatkan kesejahteraan masyarakat.

\section{Undang undang Nomor 11 Tahun 2009 tentang}

\section{Kesejahteraan Sosial}

Undang undang Nomor 11 Tahun 2009 tentang Kesejahteraan Sosial mengamanatkan bahwa sebagai bentuk peran serta masyarakat di dalam penyelenggaraan kesejahteraan sosial, maka dunia usaha mempunyai tanggung jawab sosial untuk turut menjadi mitra pemerintah penyelenggaraan kesejahteraan sosial secara melembaga dan berkelanjutan. Penyelenggara Kesejahteraan Sosial yang dimaksud adalah pemerintah pusat dan pemerintah daerah termasuk di dalamnya Provinsi Lampung.

Beberapa pasal yang mengatur mengenai hal ini adalah Pasal 25, 38, dan 40 .

Pasal 25 menyatakan bahwa tanggung jawab Pemerintah dalam menyelenggarakan kesejahteraan sosial meliputi juga mendorong dan memfasilitasi masyarakat serta dunia usaha dalam melaksanakan tanggung jawab.

Pasal 38 (1): Masyarakat mempunyai kesempatan yang seluasluasnya untuk berperan dalam penyelenggaraan kesejahteraan sosial. (2) Peran sebagaimana dimaksud pada ayat (1) dapat dilakukan 
oleh: a. perseorangan; b. keluarga; c. organisasi keagamaan; d. organisasi sosial kemasyarakatan; e. lembaga swadaya masyarakat; $\mathrm{f}$. organisasi profesi; g. badan usaha; h. lembaga kesejahteraan sosial; dan i. lembaga kesejahteraan sosial asing. (3) Peran sebagaimana dimaksud pada ayat (2) dilakukan untuk mendukung keberhasilan penyelenggaraan kesejahteraan sosial.sosialnya. Pasal 40: Peran badan usaha sebagaimana dimaksud dalam Pasal 38 huruf g dalam penyelenggaraan kesejahteraan sosial dilakukan sebagai tanggung jawab sosial dan lingkungan sesuai dengan ketentuan peraturan perundang-undangan.

\section{Undang-Undang Nomor 32 Tahun 2009 tentang Perlindungan dan Pengelolaan Lingkungan Hidup}

Materi dari undang-undang ini sudah sangat jelas mengatur tentang hak dan kewajiban setiap orang, termasuk badan usaha, untuk merawat dan melindungi lingkungan hidup. Lingkungan hidup yang baik merupakan bagian yang tidak terlepas dari sasaran TSP. Pasal 65 menetapkan:

(1) Setiap orang berhak atas lingkungan hidup yang baik dan sehat sebagai bagian dari hak asasi manusia.

(2) Setiap orang berhak mendapatkan pendidikan lingkungan hidup, akses informasi, akses partisipasi, dan akses keadilan dalam memenuhi hak atas lingkungan hidup yang baik dan sehat.

(3) Setiap orang berhak mengajukan usul dan/atau keberatan terhadap rencana usaha dan/atau kegiatan yang diperkirakan dapat menimbulkan dampak terhadap lingkungan hidup.

Sedangkan Pasal 67 menyatakan setiap orang berkewajiban memelihara kelestarian fungsi lingkungan hidup serta mengendalikan pencemaran dan/atau kerusakan lingkungan hidup. 
Mengingat bahwa lingkungan hidup yang baik dan sehat merupakan hak asasi bagi setiap warga negara Indonesia, maka seluruh pemangku kepentingan termasuk di dalamnya badan usaha berkewajiban untuk melakukan perlindungan dan pengelolaan lingkungan hidup dalam pelaksanaan pembangunan berkelanjutan.

Hal ini dimaksudkan agar lingkungan hidup Indonesia dapat tetap menjadi sumber dan penunjang hidup bagi rakyat Indonesia

54 serta makhluk hidup lain. Dalam kaitannya dengan masalah TSP, maka keberadaan perusahaan selain dituntut memperhatikan aspek profit dan people juga dituntut memperhatikan aspek planet untuk keberlangsungan kehidupan bersama.

\section{Undang-Undang Nomor 12 Tahun 2011 tentang Pembentukan Peraturan Perundang-undangan}

Dalam undang-Undang ini mengatur juga tentang partisipasi masyarakat, yaitu yang terdapat dalam Pasal 96 dimana dinyatakan:

(1) Masyarakat berhak memberikan masukan secara lisan dan/ atau tertulis dalam Pembentukan Peraturan Perundangundangan.

(2) Masukan secara lisan dan/atau tertulis sebagaimana dimaksud pada ayat (1) dapat dilakukan melalui: a. rapat dengar pendapat umum; b. kunjungan kerja; c. sosialisasi; dan/atau d. seminar; d. seminar, lokakarya, dan/atau diskusi.

(3) Masyarakat sebagaimana dimaksud pada ayat (1) adalah orang perseorangan atau kelompok orang yang mempunyai kepentingan atas substansi Rancangan Peraturan Perundangundangan.

(4) Untuk memudahkan masyarakat dalam memberikan masukan secara lisan dan/atau tertulis sebagaimana dimaksud pada ayat 
(1), setiap Rancangan Peraturan Perundang-undangan harus dapat diakses dengan mudah oleh masyarakat.

Berdasarkan ketentuan di atas, maka masyarakat berhak memberikan masukan lisan atau tulisan dalam rangka penyiapan atau pembahasan rancangan undang-undang dan rancangan peraturan daerah. Ini berarti daerah berhak mengatur rumah tangganya sendiri, termasuk peluang untuk memanfaatkan secara optimal program Community Development (CD)/Corporate Social Responsibility (CSR) dalam mendukung pembangunan daerah.

\section{Peraturan Pemerintah Nomor 27 Tahun 1999 Tentang Analisis Mengenai Dampak Lingkungan Hidup}

Peraturan Pemerintah ini mewajibkan adanya analisis mengenai dampak lingkungan hidup bagi setiap usaha dan/atau kegiatan yang kemungkinan dapat menimbulkan dampak besar dan penting. Sebagaimana dinyatakan di dalam Pasal 3 ayat (2) bahwa jenis usaha dan/atau kegiatan sebagaimana dimaksud pada ayat (1) yang wajib memiliki analisis mengenai dampak lingkungan hidup ditetapkan oleh Menteri setelah mendengar dan memperhatikan saran dan pendapat Menteri lain dan/atau Pimpinan Lembaga Pemerintah Non Departemen yang terkait.

Di dalam proses penyusunan analisis dampak lingkungan hidup tersebut di atas, masyarakat wajib dilibatkan di dalamnya. Pasal 33 ayat (1) menyatakan setiap usaha dan/atau kegiatan sebagaimana dimaksud dalam Pasal 3 ayat (2) wajib diumumkan terlebih dahulu kepada masyarakat sebelum pemrakarsa menyusun analisis mengenai dampak lingkungan hidup. Pasal 34 ayat (1) disebutkan bahwa warga masyarakat yang berkepentingan wajib dilibatkan dalam proses penyusunan kerangka acuan, penilaian 
kerangka acuan, analisis dampak lingkungan hidup, rencana pengelolaan lingkungan hidup, dan rencana pemantauan lingkungan hidup.

Setiap usaha dan/atau kegiatan pada dasarnya menimbulkan dampak terhadap lingkungan, terlebih usaha di bidang sumber daya alam dapat menimbulkan dampak besar dan penting terhadap lingkungan hidup. Oleh karena itu, analisis mengenai

56 dampak lingkungan hidup merupakan syarat yang harus dipenuhi untuk mendapatkan izin melakukan usaha dan/atau kegiatan. Hal itu merupakan konsekuensi dari kewajiban setiap orang untuk memelihara kelestarian fungsi lingkungan hidup serta mencegah dan menanggulangi pencemaran dan perusakan lingkungan hidup sebagai realisasi dari TSP pada lingkungannya.

\section{Peraturan Pemerintah Nomor 79 Tahun 2005 Tentang Pedoman Pembinaan dan Pengawasan Penyelenggaraan Pemerintahan Daerah}

Peraturan Pemerintah ini mengatur mengenai tata cara pengawasan peraturan daerah dan peraturan kepala daerah serta evaluasi rancangan peraturan daerah dan rancangan peraturan kepala daerah. Di dalam Pasal 37 dinyatakan:

(1) Peraturan Daerah dan Peraturan Kepala Daerah disampaikan kepada Pemerintah paling lama 7 (tujuh) hari sejak ditetapkan.

(2) Pemerintah melakukan pengawasan terhadap Peraturan Daerah dan Peraturan Kepala Daerah.

(3) Pelaksanaan pengawasan sebagaimana dimaksud pada ayat (1) dilakukan oleh Menteri.

(4) Peraturan Daerah sebagaimana dimaksud pada ayat (1) yang bertentangan dengan kepentingan umum dan/atau peraturan 
perundang-undangan yang lebih tinggi dapat dibatalkan dengan Peraturan Presiden berdasarkan usulan Menteri.

(5) Peraturan Kepala Daerah sebagaimana dimaksud pada ayat (1) yang bertentangan dengan kepentingan umum, Peraturan Daerah dan peraturan perundang-undangan yang lebih tinggi dapat dibatalkan dengan Peraturan Menteri.

Sementara itu di dalam Pasal 43 menyatakan bahwa Dewan Perwakilan Rakyat Daerah sesuai dengan fungsinya dapat melakukan pengawasan atas pelaksanaan urusan Pemerintahan Daerah di dalam wilayah kerjanya sesuai dengan peraturan perundang-undangan. Fungsi pengawasan Dewan Perwakilan Rakyat Daerah terhadap pemerintah daerah tersebut bersifat pengawasan kebijakan dan bukan pengawasan teknis. Ketentuan tersebut dimaksudkan untuk memberikan kesempatan dan keleluasaan kepada daerah otonom dalam mengatur dan mengurus kepentingan masyarakat setempat secara bertanggung jawab menurut prakarsa sendiri serta berdasarkan aspirasi masyarakat, sesuai dengan peraturan perundang-undangan.

\section{Peraturan Pemerintah Nomor 38 Tahun 2007 Tentang Pembagian Urusan Pemerintahan Antara Pemerintah, Pemerintahan Daerah Provinsi dan Pemerintahan \\ Daerah Kabupaten/Kota}

Di dalam Peraturan Pemerintah di atas mengatur tentang urusan pemerintahan yang menjadi kewenangan pemerintahan daerah, yaitu Pasal 6 dan Pasal 7. Berdasarkan ketentuan pasal-pasal tersebut terlihat bahwa pemerintah daerah berwenang untuk mengatur penyelenggaraan TSP. Selengkapnya Pasal 6 menyatakan: 
(1) Pemerintahan daerah provinsi dan pemerintahan daerah bupaten/kota mengatur dan mengurus urusan pemerintahan yang berdasarkan kriteria pembagian urusan pemerintahan sebagaimana dimaksud dalam Pasal 4 ayat (1) menjadi kewenangannya.

(2) Urusan pemerintahan sebagaimana dimaksud pada ayat (1) terdiri atas urusan wajib dan urusan pilihan. Selanjutnya Pasal 7 menyatakan:

(1) Urusan wajib sebagaimana dimaksud dalam Pasal 6 ayat (2) adalah urusan pemerintahan yang wajib diselenggarakan oleh pemerintahan daerah provinsi dan pemerintahan daerah kabupaten/kota, berkaitan dengan pelayanan dasar.

(2) Urusan wajib sebagaimana dimaksud pada ayat (1) meliputi: pendidikan; kesehatan; lingkungan hidup; pekerjaan umum; penataan ruang; perencanaan pembangunan; perumahan; kepemudaan dan olahraga; penanaman modal; koperasi dan usaha kecil dan menengah; kependudukan dan catatan sipil; ketenagakerjaan; ketahanan pangan; pemberdayaan perempuan dan perlindungan anak; keluarga berencana dan keluarga sejahtera; perhubungan; komunikasi dan informatika; pertanahan; kesatuan bangsa dan politik dalam negeri; otonomi daerah, pemerintahan umum, administrasi keuangan daerah, perangkat daerah, kepegawaian, dan persandian; pemberdayaan masyarakat desa; sosial; kebudayaan; statistik; kearsipan; dan perpustakaan.

(3) Urusan pilihan sebagaimana dimaksud dalam Pasal 6 ayat (2) adalah urusan pemerintahan yang secara nyata ada dan berpotensi untuk meningkatkan kesejahteraan masyarakat sesuai dengan kondisi, kekhasan, dan potensi unggulan daerah yang bersangkutan. 
(4) Urusan pilihan sebagaimana dimaksud pada ayat (3) meliputi: kelautan dan perikanan; pertanian; kehutanan; energi dan sumber daya mineral; pariwisata; industri; perdagangan; dan ketransmigrasian.

(5) Penentuan urusan pilihan ditetapkan oleh pemerintahan daerah.

16. Peraturan Pemerintah Nomor 19 Tahun 2010 Tentang

Tata Cara Pelaksanaan Tugas dan Wewenang Serta

Kedudukan Keuangan Gubernur Sebagai Wakil

Pemerintah di Wilayah Provinsi

Berdasarkan Peraturan Pemerintah ini, Gubernur sebagai wakil Pemerintah memiliki tugas di samping melakukan koordinasi penyelenggaraan pemerintahan juga melaksanakan pembinaan dan pengawasan penyelenggaraan pemerintahan daerah kabupaten/kota. Mengacu pada tugas tersebut, maka Gubernur dapat mengawasi peraturan-peraturan daerah kabupaten/kota termasuk Perda tentang TSP yang akan dibuat nantinya. Hal ini didasarkan pada Pasal 3 dan Pasal 9 dari Peraturan Pemerintah, yang di dalam Pasal 3 ayat (1) menyatakan bahwa Gubernur sebagai wakil Pemerintah memiliki tugas melaksanakan urusan pemerintahan meliputi: pembinaan dan pengawasan penyelenggaraan pemerintahan daerah kabupaten/kota.

Sedangkan pada Pasal 9 ayat (2) disebutkan bahwa Gubernur dalam melaksanakan pengawasan penyelenggaraan pemerintahan daerah kabupaten/kota sebagaimana dimaksud dalam Pasal 3 ayat (1) huruf d melalui:

a. pengawasan pelaksanaan urusan pemerintahan yang dilaksanakan oleh pemerintah daerah kabupaten/kota; 
b. pengawasan peraturan daerah dan peraturan kepala daerah kabupaten/kota;

c. usul pembatalan peraturan daerah kabupaten/kota kepada Presiden melalui Menteri Dalam Negeri;

\section{Peraturan Menteri BUMN Nomor Per-05/MBU/2007 Tentang Program Kemitraan BUMN dengan Usaha}

Peraturan Menteri BUMN ini sebagai pelaksanaan dari Pasal 88 Undang-Undang Nomor 19 Tahun 2003 tentang BUMN yang mewajibkan BUMN melaksanakan program PKBL. Pasal 2ayat (1) dari Peraturan Menteri BUMN menyatakan; "Perum dan Persero wajib melaksanakan Program Kemitraan dan Program BL dengan memenuhi ketentuan-ketentuan yang diatur dalam Peraturan ini”. Selanjutnya Pasal 9 menyatakan:

(1) Dana Program Kemitraan bersumber dari :

a. Penyisihan laba setelah pajak maksimal sebesar 2\% (dua persen);

b. Jasa administrasi pinjaman/marjin/bagi hasil, bunga deposito dan/atau jasa giro dari dana Program Kemitraan setelah dikurangi beban operasional;

c. Pelimpahan dana Program Kemitraan dari BUMN lain, jika ada.

(2) Dana Program BL bersumber dari :

a. Penyisihan laba setelah pajak maksimal sebesar 2\% (dua persen);

b. Hasil bunga deposito dan atau jasa giro dari dana Program BL. 
Menurut Pasal 1 ayat (6) Peraturan Menteri BUMN: Per-05/ MBU/2007 Program Kemitraan BUMN dengan Usaha Kecil, yang selanjutnya disebut Program Kemitraan, adalah program untuk meningkatkan kemampuan usaha kecil agar menjadi tangguh dan mandiri melalui pemanfaatan dana dari bagian laba BUMN. Sedangkan pada Pasal 1 ayat (7) dijelaskan bahwa Program Bina Lingkungan, yang selanjutnya disebut Program BL, adalah program pemberdayaan kondisi sosial masyarakat oleh BUMN melalui pemanfaatan dana dari bagian laba BUMN. Program Bina Lingkungan, meliputi: bantuan korban bencana alam; bantuan pendidikan dan/atau pelatihan; bantuan peningkatan kesehatan; bantuan pengembangan prasarana dan/atau sarana umum; bantuan sarana ibadah; dan bantuan pelestarian alam.

Selanjutnya, di dalam Permen BUMN menjelaskan bahwa sumber dana PKBL berasal dari penyisihan laba bersih perusahaan sebesar 2 persen yang dapat digunakan untuk Program Kemitraan ataupun Bina Lingkungan. Peraturan ini juga menegaskan bahwa pihak-pihak yang berhak mendapat pinjaman adalah pengusaha beraset bersih maksimal Rp 200 juta atau beromset paling banyak Rp 1 miliar per tahun.

\section{Peraturan Menteri Dalam Negeri Nomor 53 Tahun 2011}

\section{Tentang Pembentukan Produk Hukum Daerah}

Menurut Pasal 2 Peraturan Menteri Dalam Negeri Nomor 53 Tahun 2011, Produk hukum daerah bersifat pengaturan dan penetapan. Adapun bentuk produk hukum daerah yang bersifat pengaturan, menurut Pasal 3 dapat berbentuk (a) Perda atau nama lainnya; (b) Perkada; dan (c) PB KDH. Menurut Pasal 4, Perda atau nama lainnya tersebut terdiri atas Perda provinsi, dan Perda kabupaten/kota. 
Selanjutnya di dalam penyusunan produk hukum, Pasal 15 menyatakan: "Penyusunan produk hukum daerah yang bersifat pengaturan berbentuk Perda atau nama lainnya sebagaimana dimaksud dalam Pasal 3 huruf a dilakukan berdasarkan Prolegda".

\section{International Standard Organization 26000}

ISO 26000, merupakan standar internasional dalam bidang 62 Corporate Social Responsibility. Didasarkan pada Pemahaman bahwa Sosial Responsibility sangat penting bagi keberlanjutan usaha. Fokus ISO adalah tata kelola organisasi, Hak Asasi manusia (HAM), ketenagakerjaan, lingkungan, fair operating/praktek operasi yang adil, isu konsumen dan Pengembangan masyarakat. ISO sendiri bertujuan membantu berbagai bentuk organisasi dalam pelaksanaan social responsibility.

Dengan cara memberikan pedoman praktis, serta memperluas pemahaman publik terhadap social responsibility. ISO 26000 merupakan sesuatu yang tidak bisa ditawar. Meskipun ISO ini dinyatakan sebagai sesuatu yang tidak wajib, namun bisa dijadikan sebagai rujukan atau pedoman dalam pembentukan pedoman prinsip pelaksanaan CSR di Indonesia. Dalam ISO 26000 ada panduan yang sangat rinci yaitu tanggung jawab sosial. Ada 7 prinsip dalam melakukan tanggung jawab sosial perusahaan. Setiap tahap dari tanggung jawab sosialnya yaitu: 1) Akuntabilitas; 2) Transparansi; 3) Perilaku etis; 4) Menghargai kepentingan stakeholders; 5) Menghargai hukum yang berlaku; 6) Menghargai perilaku atau norma internasional; dan, 7) Menghargai hak asasi manusia;

Dari ketentuan peraturan perundang-undangan yang berkenaan dengan kewenangan pemerintahan provinsi dalam menata dan menyelenggarakan TSP yang telah dipetakan di atas, dapat dilihat 
bahwa terdapat sinkronisasi yang menunjukkan pemerintah daerah berwenang dalam melakukan pengaturan tentang TSP untuk proses percepatan dan pemerataan pembangunan. 


\section{BAGIAN V \\ Penutup}

R ealitas saat ini yang tak bisa dipungkiri tentunya adalah - masih banyak perusahaan terutama di daerah yang belum belum melaksanakan Corporate Social Responsibilty (CSR) atau Tanggung Jawab Sosial Perusahaan (TSP). Hal ini menunjukkan bahwa perusahaan tidak peduli pada masyarakat dan lingkungan di sekitarnya. Sebaliknya justru keberadaan perusahaan sering menimbulkan dampak negatif, baik di bidang sosial, ekonomi, dan lingkungan hidup.

Akibatnya di banyak tempat masih sering terjadi gesekan atau konflik antara masyarakat setempat dengan perusahaan. Sementara itu perusahaan yang telah melaksanakan CSR/TSP pada umumnya masih dalam bentuk charity yang bersifat spontan dan ad hoc atau sementara, dan belum sampai tingkat community development. TSP dalam bentuk charity tidak akan banyak membantu pemerintah daerah dalam menangani permasalahan sosial seperti tingginya kemiskinan, pengangguran, dan kerusakan lingkungan.

Pendekatan CSR/TSP hendaknya dilakukan secara holistik yaitu pendekatan CSR/TSP yang lebih menekankan pada keberlanjutan pengembangan masyarakat (community development). Dengan community development, masyarakat menjadi berdaya baik secara ekonomi, sosial, dan budaya secara berkelanjutan (sustainability) sehingga perusahaan juga dapat terus berkembang secara berkelanjutan. 
Orientasi pengaturan hukum CSR/TSP di daerah sendiri dilakukan dengan maksud memberi kepastian dan perlindungan hukum atas pelaksanaan program tanggungjawab sosial perusahaan bertujuan sebagai berikut:

a. terwujudnya batasan yang jelas tentang tanggung jawab sosial dan lingkungan;

b. terpenuhinya penyelenggaraan tanggungjawab sosial perusahaan sesuai dengan peraturan perundang-undangan yang berlaku;

c. terwujudnya kepastian dan perlindungan hukum bagi pelaku dunia usaha dalam pelaksanaan tanggungjawab sosial perusahaan;

d. melindungi perusahaan agar terhindar dari pungutan liar yang dilakukan pihak-pihak yang tidak berwenang;

e. meminimalisir dampak negatif keberadaan perusahaan dan mengoptimalkan dampak positif keberadaan perusahaan; dan

f. terprogramnya pemberian apresiasi dan penghargaan kepada dunia usaha yang telah melakukan TSP.

Landasan filosofis pengaturan Tanggung Jawab Sosial Perusahaan di daerah sendiri adalah penerapan nilai-nilai Pancasila khususnya sila kedua, keempat, dan kelima dalam operasi bisnisnya. Dalam sistem ekonomi Pancasila tujuan perusahaan adalah melayani kepentingan ekonomi semua golongan yang tersangkut dalam perusahaan baik yang ada di dalam maupun yang di luar lingkungan perusahaan, baik yang mempengaruhi maupun yang dipengaruhi perusahaan yang disebut dengan stakeholders, yaitu antara lain: pemilik modal, karyawan, langganan, masyarakat dan lingkungan sekitar, serta pemerintah. Nilai- nilai Pancasila dari perusahaan yang melaksanakan TSP tidak hanya sekedar berorien- 
tasi pada keuntungan semata melainkan berorientasi pada triple bottom line, yaitu profit, people, dan planet. Perusahaan tidak lagi berpijak pada shareholder theory melainkan pada stakeholders theory.

Sementara landasan sosiologisnya adalah keberadaan perusahaan ternyata belum memberikan banyak manfaat bagi masyarakat di sekitarnya. Masyarakat justru merasakan dampak negatif yang ditimbulkan oleh perusahaan, baik di bidang sosial maupun ling66 kungan hidup. Kenyataan inilah yang menjadi faktor utama atau setidak-tidaknya yang memicu terjadinya konflik antar masyarakat, perusahaan dan pemerintah sebagaimana yang sekarang ini banyak terjadi di masyarakat. Oleh karena itu perlu dilakukan penataan program TSP agar keberadaan suatu perusahaan dapat memberikan manfaat tidak saja kepada masyarakat dan stakeholders lainnya tetapi juga pada perusahaan itu sendiri.

Pengaturan tentang Tanggung Jawab Sosial Perusahaan dalam peraturan daerah akan memiliki landasan hukum yang kuat untuk menyelenggarakan TSP demi kesejahteraan masyarakat. Melalui Peraturan Daerah diharapkan dapat menjamin kepastian hukum dan rasa keadilan pada seluruh stakeholders. 


\section{Daftar Pustaka}

\section{Buku}

Carroll, "A Three-Dimensional Conceptual Model of Corporate Social Performance", Academy of Management Review, Vol. 4. No. 4, 1979

FX. Adji Samekto. Kapitalisme, Modernisasi, dan Kerusakan Lingkungan. Yogyakarta: Genta Press, 2008

G. Suprayitno., et al. Internalisasi Good Corporate Governance dalam Proses Bisnis. Jakarta: The Indonesian Institute for Corporate Governance, 2005

Jackie Ambadar,CSR dalam Praktik di Indonesia. Jakarta: Elex Media Komputindo, 2008

Kementerian Lingkungan Hidup. 2012.

Laporan Program Kemitraan dan Bina Lingkungan PT. Bio farma (PERSERO), 2007.

Mukti Fajar. Tanggung Jawab Sosial Perusahaan di Indonesia: Studi Tentang Penerapan Ketentuan Corporate Sosial Responbility pada Perusabaan Multi Nasional, Swasta Nasional dan Badan Usaha Milik Negara. Yogyakarta: Pustaka Pelajar, 2010

Poerwanto. Budaya Perusahaan. Yogyakarta: Pustaka Pelajar, 2008 Solly Lubis, Landasan dan Teknik Perundang-undangan, PT. Mandar Maju, Bandung, 1995

Sudharto P. Hadi dan FX. Adji Samekto. Dimensi Lingkungan dalam Bisnis Kajian Tanggung Jawab Sosial Perusabaan pada Lingkungan. Semarang: Badan Penerbit Universitas Diponegoro, 2007 Sukanda Husin. Penegakkan Hukum Lingkungan Indonesia. Jakarta: Sinar Grafika, 2009

Suporahardjo (Ed). Kekerasan dalam Kebijakan Pengelolaan Sumber Daya Hutan: Dalam Perspektif Hukum. Bogor: Pustaka Latin, 2006 
Surachmin, 225 Asas Dan Prinsip Hukum Serta Penyelenggaraan Negara, Yayasan Gema Yustisia Indonesia, Jakarta

\section{Jurnal}

Manuel Castelo Branco dan Lúcia Lima Rodriguez, Positioning Stakeholder Theory within the Debate on Corporate Social Responsibility, Electronic Journal of Business Ethics and Organizaion (EJBO), Vol. 12, No. 1 (2007)

68 Soeharto Prawirokusumo, Perilaku Bisnis Modern - Tinjanan pada Etika Bisnis dan Tanggung Jawab Sosial, Jurnal Hukum Bisnis, Vol 22, No 4, 2003

\section{Makalah}

Badarudin, Implementasi Tanggung Jawab Sosial Perusahaan terhadap Masyarakat melalui Pemanfaatan Potensi Modal Sosial, Pidato Pengukuhan Jabatan Guru Besar Tetap dalam Bidang Ilmu Sosiologi Perkotaan pada Fakultas Ilmu Sosial Politik dan Ilmu Politik diucapkan di hadapan Rapat Terbuka Universitas Sumatera Utara pada 12 April 2008.

Edi Suharto, Corporate Social Responsibility, Konsep dan Perkembangan Pemikiran, Makalah disampaikan pada Workshop Tanggung jawab Sosial Perusahaan, Universitas Islam Indonesia (UII), Yoyakarta, Tanggal 6-8 Mei 2008.

\section{Online}

A.F. Elly Erawaty, Persoalan Hukum Seputar Tanggung Jawab Sosial dan Lingkungan Perseroan dalam Perundang-Undangan Ekonomi Indonesia, http://saepudinonline.wordpress.com/2011/04/11/persoalanhukum-seputar-tanggung-jawab-sosial-dan-lingkungan-perseroa n-dalam-perundang-undangan-ekonomi-indonesia/

Edi Suharto, Menggagas Standar Audit Program CSR Initiating Audit Standard of CSR Program, http://www.policy.hu/suharto/ Naskah\%20PDF/CSRAudit.pdf 
Hasim Purba, Implementasi Prinsip Corporate Social Responsibility (CSR) dalam Sistem Hukum Indonesia, http://repository.usu.ac.id/ bitstream/123456789/18416/1/equ-feb2008-1 3\%20 (1). pdf, Diakses tanggal 12 Nopember 2010.

Rahmatullah, CSR dan Kepentingan Pemerintah Daerah. http://rahmatullah.banten-institute.org/2011/05/csr-dan-kepentingan-pemerintah-daerah.html. Diakses tanggal 15 Januari 2012.

Sri Yuliani, Corporate Social Responsibility (CSR) Pertanggungjawaban Publik Sektor Bisnis dan Implikasinya Bagi Studi Administrasi Publik. http://sriyuliani.staff.fisip.uns.ac.id. Dikases tanggal 1 Nopember 2011.

Trisoko S, Pengaturan CSR (Corporate Social Responsibility) di Indonesia, http://breath4justice.wordpress.com/2011/04/17/pengaturancsr-corporate-social-responsibility-di-indonesia/ 


\section{Indeks}

A

akuntabilitas 10

C

corporate $1,2,10,14,17,25,26$, $27,49,69$

CSR $1,2,3,4,5,6,7,8,9,10$, $14,17,18,20,21,22,23$, $25,26,27,28,29,30,31$, $32,33,34,41,46,48,49$, $50,51,52,55,62,64,65$, $67,68,69$

E

efisiensi 30

ekonomi 1, 4, 6, 8, 10, 11, 13, 16, $17,20,23,26,28,30,31$, $44,51,64,65,68$

$\mathbf{L}$

lingkungan $1,2,3,4,5,6,7,8$, $11,14,17,18,19,20,23$, $24,25,26,27,30,32,41$, $44,45,50,51,53,54,55$, $56,58,62,64,65,66,68$

$\mathbf{P}$

pembangunan berkelanjutan 18 ,

54

pengusaha $22,46,61$

Perseroan Terbatas 6, 11, 12, 17, $20,24,25,39,40,50$

perusahaan $1,2,3,4,5,6,7,8$, $10,11,12,13,14,15,16$,

$17,18,19,20,21,22,23$, $24,25,26,27,36,41,42$, $45,46,48,49,50,51,52$, $54,61,62,64,65,66$
S

sanksi $6,11,12,20,24,25,48$, $49,50,51,52$

Sosial $6,8,10,11,16,17,18,19$, $21,22,23,25,36,38,40$, $49,50,51,52,62,64,65$, $66,67,68$

Stakeholder 13, 68

\section{$\mathbf{T}$}

tanggung jawab $1,4,6,7,9,10$, $11,12,13,14,15,16,17$, $20,23,24,25,26,29,32$, $35,36,41,48,52,53,62$, 65

U

Undang-Undang iv, 6, 11, 17, 20, $24,25,35,38,39,41,43$, $44,45,46,47,48,49,50$, $53,54,60$ 


\section{Tentang Penulis}

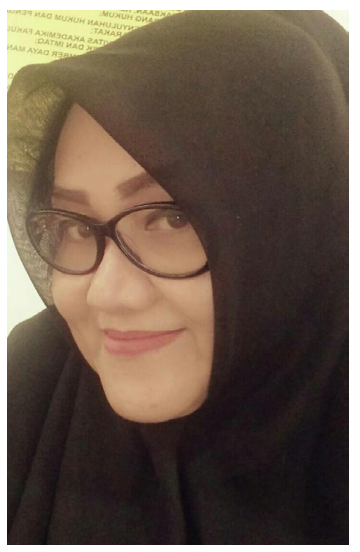

Lina Maulidiana, anak dari pasangan pasangan Letkol CZI Adji Rais dan Ida Rukida lahir pada 8 Desember 1970 di Singkawang Kalimantan Barat. Setelah menamatkan SMA Negeri Way Halim pada tahun 1989, Lina melanjutkan studi pada Universitas Bandar Lampung dan lulus tahun 1993.

Pada Tahun 1993 memulai karir sebagai asisten dosen di Universitas Saburai Bandar Lampung, sebelum akhirnya diangkat sebagai Dosen Tetap Fakultas Hukum Yayasan Pendidikan Saburai pada tahun 2006. Pada tahun 2007 melanjutkan studi pada Universitas Lampung melalui Beasiswa Program Pasca Sarjana (BPPS) Kopertis Wilayah II dan lulus tahun 2009. Pada tahun 2011 Lina memperoleh sertifikat pendidik professional. Saat ini Lina tengah menempuh pendidikan doktoral di PDIH Universitas Borobudur.

Jabatan struktural yang pernah dipangkunya adalah Sekretaris Jurusan pada Program Studi IImu Hukum Universitas Saburai Bandar Lampung pada tahun 2004, Ketua Jurusan pada tahun 2006, Pembantu Dekan I pada tahun 2008-2012 dan dipercaya sebagai Pembantu Rektor I tahun 2012-2016. Pada tahun 2016 sampai kini dipercaya sebagai Dekan Fakultas Hukum. 
Beberapa organisasi profesi yang diikuti istri dari Umar Usman dan ibu dari Raisya Augusta Putri (alm), Yolanda Septiani Thalita dan Jenika Tri Lestari ini antara lain Asosiasi Dosen Republik Indonesia (ADRI), Asosiasi Pimpinan Perguruan Tinggi Hukum Indonesia (APPTHI) dan Asosiasi Pengajar dan Peneliti Hukum Ekonomi Islam Indonesia (APPHEISI). Penulis juga pernah dipercaya sebagai pengawas terhadap Notaris di wilayah Kab.Lamteng, Metro dan Lamtim Periode 2013-2016.

Selain aktif mengajar dan mengikuti kegiatan ilmiah, penulis juga telah mempublikasikan karyanya pada Jurnal Nasional yaitu : Implementasi Kontrak SGU Pada PT. Dipo Star Finance Bandar Lampung Jurnal Legalita STIH Kotabumi Vol X No 2 November 2012 (ISSN: 1414-2480). Penerapan Prinsip-prinsip Murabahah Dalam Perjanjian Islam Jurnal Keadilan Progresif Prodi IImu Hukum UBL Vol 3 No 2 September 2012 (ISSN 2087-2089). Implementasi Tanggung Jawab Sosial Pada PTPN VII Bandar Lampung Jurnal IImu Hukum Vol 1 Nomor 1, Januari 2012, (ISSN : 2089-5909) Penerbit LPPM USBRJ. Studi Komparatif Antara Perjanjian Leasing Dengan Perjanjian Pembiayaan Konsumen Jurnal IImu Hukum Vol 2 Nomor 1, Januari 2013, (ISSN : 2089-5909) Penerbit LPPM USBRJ. Tinjauan Yuridis Akibat Hukum Kepailitan dan Penundaan Pembayaran Jurnal Legalita STIH Kotabumi Vol XI No 1, April 2013 (ISSN: 1414-2480) dan Implementation Of Franchise Agreement Perspective In Contract Law dalam Saburai International Journal Of Social Sciences And Development “Volume 1 nomor 1 (2017).

Pengabdian Masyarakat yang pernah dilaksanakannya antara lain Penyuluhan tentang peranan perempuan dalam menciptakan lingkungan yang sehat, di Desa Kebagusan Kec.Gedung Tataan (2011), Sosialisasi UU Nomor23 Tahun2004 Tentang PKDRT, di Desa Gedong Dalom Kecamatan Way Lima Kabupaten Pesawaran(2012). Penyuluhan Peningkatan Kesejahteraan Masyarakat DesaMelalui 
KUD di Desa Binaan Universitas Saburai yakni Desa Gebang Kecamatan Padang Cermin Kab.Pesawaran(2013) dan sebagai tim dalam pembuatan Naskah Akademik Raperda di Kabupaten Lampung Timur. 